NBER WORKING PAPER SERIES

\title{
ANOMALIES AND MARKET EFFICIENCY
}

\author{
G. William Schwert
}

Working Paper 9277

http://www.nber.org/papers/w9277

\author{
NATIONAL BUREAU OF ECONOMIC RESEARCH \\ 1050 Massachusetts Avenue \\ Cambridge, MA 02138 \\ October 2002
}

Forthcoming in the Handbook of the Economics of Finance, edited by George Constantinides, Milton Harris, and René M. Stulz. The Bradley Policy Research Center, William E. Simon Graduate School of Business Administration, University of Rochester, provided support for this research. I received helpful comments from Yakov Amihud, Brad Barber, John Cochrane, Eugene Fama, Murray Frank, Ken French, David Hirshleifer, Tim Loughran, Randall Mørck, Jeff Pontiff, Jay Ritter, René Stulz, A. Subrahmanyam, Sheridan Titman, Janice Willett, and Jerold Zimmerman. The views expressed herein are those of the author and do not necessarily reflect the views of the National Bureau of Economic Research.

(C) 2002 by G. William Schwert. All rights reserved. Short sections of text, not to exceed two paragraphs, may be quoted without explicit permission provided that full credit, including $\mathbb{C}$ notice, is given to the source. 
Anomalies and Market Efficiency

G. William Schwert

NBER Working Paper No. 9277

October 2002

JEL No. G14, G12, G34, G32

\begin{abstract}
Anomalies are empirical results that seem to be inconsistent with maintained theories of asset-pricing behavior. They indicate either market inefficiency (profit opportunities) or inadequacies in the underlying asset-pricing model.

The evidence in this paper shows that the size effect, the value effect, the weekend effect, and the dividend yield effect seem to have weakened or disappeared after the papers that highlighted them were published. At about the same time, practitioners began investment vehicles that implemented the strategies implied by some of these academic papers.

The small-firm turn-of-the-year effect became weaker in the years after it was first documented in the academic literature, although there is some evidence that it still exists. Interestingly, however, it does not seem to exist in the portfolio returns of practitioners who focus on small-capitalization firms.

All of these findings raise the possibility that anomalies are more apparent than real. The notoriety associated with the findings of unusual evidence tempts authors to further investigate puzzling anomalies and later to try to explain them. But even if the anomalies existed in the sample period in which they were first identified, the activities of practitioners who implement strategies to take advantage of anomalous behavior can cause the anomalies to disappear (as research findings cause the market to become more efficient).
\end{abstract}

G. William Schwert

Simon School of Business

University of Rochester

Rochester, NY 14627

and NBER

Schwert@schwert.ssb.rochester.edu 


\section{Introduction}

Anomalies are empirical results that seem to be inconsistent with maintained theories of asset-pricing behavior. They indicate either market inefficiency (profit opportunities) or inadequacies in the underlying asset-pricing model. After they are documented and analyzed in the academic literature, anomalies often seem to disappear, reverse, or attenuate. This raises the question of whether profit opportunities existed in the past, but have since been arbitraged away, or whether the anomalies were simply statistical aberrations that attracted the attention of academics and practitioners.

Surveys of the efficient markets literature date back at least to Fama (1970), and there are several recent updates, including Fama (1991) and Keim and Ziemba (2000), that stress particular areas of the finance literature. By their nature, surveys reflect the views and perspectives of their authors, and this one will be no exception. My goal is to highlight some interesting findings that have emerged from the research of many people and to raise questions about the implications of these findings for the way academics and practitioners use financial theory. ${ }^{1}$

There are obvious connections between this chapter and earlier chapters by Ritter (10 Investment Banking and Securities Issuance) and Ferson (16 - Multifactor Pricing Models), as well as later chapters by Barberis and Thaler (18 - Behavioral Issues), Cochrane (20 - New Facts in Finance), and Easley and O’Hara (21 - Market Microstructure and Asset Pricing). In fact, those chapeters draw on some of the same findings and papers that provide the basis for my conclusions.

At a fundamental level, anomalies can only be defined relative to a model of "normal"

\footnotetext{
${ }^{1}$ This chapter is not meant to be a survey of all of the literature on market efficiency or anomalies. Failure to cite particular papers should not be taken as a reflection on those papers.
} 
return behavior. Fama (1970) noted this fact early on, pointing out that tests of market efficiency also jointly test a maintained hypothesis about equilibrium expected asset returns. Thus, whenever someone concludes that a finding seems to indicate market inefficiency, it may also be evidence that the underlying asset-pricing model is inadequate.

It is also important to consider the economic relevance of a presumed anomaly. Jensen (1978) stressed the importance of trading profitability in assessing market efficiency. In particular, if anomalous return behavior is not definitive enough for an efficient trader to make money trading on it, then it is not economically significant. This definition of market efficiency directly reflects the practical relevance of academic research into return behavior. It also highlights the importance of transactions costs and other market microstructure issues for defining market efficiency.

The growth in the amount of data and computing power available to researchers, along with the growth in the number of active empirical researchers in finance since Fama's (1970) survey article, has created an explosion of findings that raise questions about the first, simple models of efficient capital markets. Many people have noted that the normal tendency of researchers to focus on unusual findings (which could be a by-product of the publication process, if there is a bias toward the publication of findings that challenge existing theories) could lead to the over-discovery of "anomalies." For example, if a random process results in a particular sample that looks unusual, thereby attracting the attention of researchers, this "sample selection bias" could lead to the perception that the underlying model was not random. Of course, the key test is whether the anomaly persists in new, independent samples.

Some interesting questions arise when perceived market inefficiencies or anomalies seem to disappear after they are documented in the finance literature: Does their disappearance reflect 
sample selection bias, so that there was never an anomaly in the first place? Or does it reflect the actions of practitioners who learn about the anomaly and trade so that profitable transactions vanish?

The remainder of this chapter is organized as follows. Section 2 discusses cross-sectional and times-series regularities in asset returns, including the size, book-to-market, momentum, and dividend yield effects. Section 3 discusses differences in returns realized by different types of investors, including individual investors (through closed-end funds and brokerage account trading data) and institutional investors (through mutual fund performance and hedge fund performance). Section 4 evaluates the role of measurement issues in many of the papers that study anomalies, including the difficult issues associated with long-horizon return performance. Section 5 discusses the implications of the anomalies literature for asset-pricing theories, and Section 6 discusses the implications of the anomalies literature for corporate finance. Section 7 contains brief concluding remarks.

\section{$2 \quad$ Selected Empirical Regularities}

\subsection{Predictable Differences in Returns Across Assets}

\section{Data Snooping}

Many analysts have been concerned that the process of examining data and models affects the likelihood of finding anomalies. Authors in search of an interesting research paper are likely to focus attention on "surprising" results. To the extent that subsequent authors reiterate or refine the surprising results by examining the same or at least positively correlated data, there is really no additional evidence in favor of the anomaly. Lo and MacKinlay (1990)

illustrate the data-snooping phenomenon and show how the inferences drawn from such exercises are misleading. 
One obvious solution to this problem is to test the anomaly on an independent sample. Sometimes researchers use data from other countries, and sometimes they use data from prior time periods. If sufficient time elapses after the discovery of an anomaly, the analysis of subsequent data also provides a test of the anomaly. I supply some evidence below on the postpublication performance of several anomalies.

\section{The Size Effect}

Banz (1981) and Reinganum (1981) showed that small-capitalization firms on the New York Stock Exchange (NYSE) earned higher average returns than is predicted by the Sharpe (1964) - Lintner (1965) capital asset-pricing model (CAPM) from 1936-75. This "small-firm effect" spawned many subsequent papers that extended and clarified the early papers. For example, a special issue of the Journal of Financial Economics contained several papers that extended the size effect literature. ${ }^{2}$

Interestingly, at least some members of the financial community picked up on the smallfirm effect, since the firm Dimensional Fund Advisors (DFA) began in 1981 with Eugene Fama as its Director of Research. ${ }^{3}$ Table 1 shows the abnormal performance of the DFA US 9-10 Small Company Portfolio, which closely mimics the strategy described by Banz (1981).

The measure of abnormal return $\alpha_{i}$ in Table 1 is called Jensen's (1968) alpha, from the following familiar model:

$$
\left(\mathrm{R}_{\mathrm{it}}-\mathrm{R}_{\mathrm{ft}}\right)=\alpha_{\mathrm{i}}+\beta_{\mathrm{i}}\left(\mathrm{R}_{\mathrm{mt}}-\mathrm{R}_{\mathrm{ft}}\right)+\varepsilon_{\mathrm{it}}
$$

where $\mathrm{R}_{\mathrm{it}}$ is the return on the DFA fund in month $t, \mathrm{R}_{\mathrm{ft}}$ is the yield on a one-month Treasury bill,

\footnotetext{
${ }^{2}$ Schwert (1983) discusses all of these papers in more detail.

${ }^{3}$ Information about DFA comes from their web page: http://www.dfafunds.com and from the Center for Research in Security Prices (CRSP) Mutual Fund database. Ken French maintains current data for the Fama-French factors on his web site: http://mba.tuck.dartmouth.edu/pages/faculty/ken.french/.
} 
and $\mathrm{R}_{\mathrm{mt}}$ is the return on the CRSP value-weighted market portfolio of NYSE, Amex, and Nasdaq stocks. The intercept $\alpha_{i}$ in (1) measures the average difference between the monthly return to the DFA fund and the return predicted by the CAPM. The market risk of the DFA fund, measured by $\beta_{\mathrm{i}}$, is insignificantly different from 1.0 in the period January 1982 - May 2002, as well as in each of the three subperiods, 1982-1987, 1988-1993, and 1994-2002. The estimates of abnormal monthly returns are between $-0.2 \%$ and $0.4 \%$ per month, although none are reliably below zero.

Thus, it seems that the small-firm anomaly has disappeared since the initial publication of the papers that discovered it. Alternatively, the differential risk premium for small-capitalization stocks has been much smaller since 1982 than it was during the period 1926-1982.

\section{The Turn-of-the-Year Effect}

Keim (1983) and Reinganum (1983) showed that much of the abnormal return to small firms (measured relative to the CAPM) occurs during the first two weeks in January. This anomaly became known as the "turn-of-the-year effect." Roll (1983) hypothesized that the higher volatility of small-capitalization stocks caused more of them to experience substantial short-term capital losses that investors might want to realize for income tax purposes before the end of the year. This selling pressure might reduce prices of small-cap stocks in December, leading to a rebound in early January as investors repurchase these stocks to reestablish their investment positions. ${ }^{4}$

\footnotetext{
${ }^{4}$ There are many mechanisms that could mitigate the size of such an effect, including the choice of a tax year different from a calendar year, the incentive to establish short-term losses before December, and the opportunities for other investors to earn higher returns by providing liquidity in December.
} 


\section{Table 1}

\section{Size and Value Effects, January 1982 - May 2002}

Performance of DFA US 9-10 Small Company Portfolio relative to the CRSP value-weighted portfolio of NYSE, Amex, and Nasdaq stocks $\left(\mathrm{R}_{\mathrm{m}}\right)$ and the one-month Treasury bill yield $\left(\mathrm{R}_{\mathrm{f}}\right)$, January 1982 - May 2002. The intercept in this regression, $\alpha_{i}$, is known as "Jensen's alpha" (1968) and it measures the average difference between the monthly return to the DFA fund and the return predicted by the CAPM.

$$
\left(\mathrm{R}_{\mathrm{it}}-\mathrm{R}_{\mathrm{ft}}\right)=\alpha_{\mathrm{i}}+\beta_{\mathrm{i}}\left(\mathrm{R}_{\mathrm{mt}}-\mathrm{R}_{\mathrm{ft}}\right)+\varepsilon_{\mathrm{it}}
$$

The last row shows the performance of the DFA US 6-10 Value Portfolio from January 1994 May 2002. Heteroskedasticity-consistent standard errors are used to compute the t-statistics.

\begin{tabular}{lllll}
\hline Sample Period & $\alpha_{\mathrm{i}}$ & $\mathrm{t}\left(\alpha_{\mathrm{i}}=0\right)$ & $\beta_{\mathrm{i}}$ & $\mathrm{t}\left(\beta_{\mathrm{i}}=1\right)$ \\
\hline
\end{tabular}

DFA 9-10 Small Company Portfolio

\begin{tabular}{llccc}
\hline $1982-2002$ & 0.0020 & 0.67 & 1.033 & 0.68 \\
$1982-1987$ & -0.0019 & -0.44 & 1.000 & 0.00 \\
$1988-1993$ & 0.0038 & 0.80 & 1.104 & 1.21 \\
$1994-2002$ & 0.0035 & 0.66 & 1.013 & 0.15 \\
\hline
\end{tabular}

DFA US 6-10 Value Portfolio

\begin{tabular}{lllll}
\hline $1994-2002$ & -0.0022 & -0.59 & 0.816 & -2.14 \\
\hline
\end{tabular}


Table 2 shows estimates of the turn-of-the-year effect for the period 1962-2001, as well as for the 1962-1979 period analyzed by Reinganum (1983), and the subsequent 1980-1989 and 1990-2001 sample periods. The dependent variable is the difference in the daily return to the CRSP NYSE small-firm portfolio (decile 1) and the return to the CRSP NYSE large-firm portfolio (decile 10$),\left(R_{1 t}-R_{10 t}\right)$. The independent variable, January, equals one when the daily return occurs during the first 15 calendar days of January, and zero otherwise. Thus, the coefficient $\alpha_{J}$ measures the difference between the average daily return during the first 15 calendar days of January and the rest of the year. If small firms earn higher average returns than large firms during the first half of January, $\alpha_{\mathrm{J}}$ should be reliably positive.

Unlike the results in Table 1, it does not seem that the turn-of-the-year anomaly has completely disappeared since it was originally documented. The estimates of the turn-of-theyear coefficient $\alpha_{\mathrm{J}}$ are around $0.4 \%$ per day over the periods $1980-1989$ and $1990-2001$, which is about half the size of the estimate over the $1962-1979$ period of $0.8 \%$. Thus, while the effect is smaller than observed by Keim (1983) and Reinganum (1983), it is still reliably positive.

Interestingly, Booth and Keim (2000) have shown that the turn-of-the-year anomaly is not reliably different from zero in the returns to the DFA 9-10 portfolio over the period 19821995. They conclude that the restrictions placed on the DFA fund (no stocks trading at less than $\$ 2$ per share or with less than $\$ 10$ million in equity capitalization, and no stocks whose IPO was less than one year ago) explain the difference between the behavior of the CRSP small-firm portfolio and the DFA portfolio. Thus, it is the lowest-priced and least-liquid stocks that apparently explain the turn-of-the-year anomaly. This raises the possibility that market microstructure effects, especially the costs of illiquidity, play an important role in explaining some anomalies (see Chapters 12 (Stoll) and 21 (Easley and O'Hara)). 


\section{Table 2}

\section{Small Firm/Turn-of-the-Year Effect, Daily Returns, 1962-2001}

$$
\left(\mathrm{R}_{1 \mathrm{t}}-\mathrm{R}_{10 \mathrm{t}}\right)=\alpha_{0}+\alpha_{\mathrm{J}} \text { January }_{\mathrm{t}}+\varepsilon_{\mathrm{t}}
$$

$\mathrm{R}_{1 \mathrm{t}}$ is the return to the CRSP NYSE small-firm portfolio (decile 1) and $\mathrm{R}_{10 \mathrm{t}}$ is the return to the CRSP NYSE large-firm portfolio (decile 10). January $=1$ when the daily return occurs during the first 15 calendar days of January, and zero otherwise. The coefficient of January measures the difference in average return between small- and large-firm portfolios during the first two weeks of the year versus other days in the year. Heteroskedasticity-consistent standard errors are used to compute the t-statistics.

\begin{tabular}{lcccc}
\hline Sample Period & $\alpha_{0}$ & $\mathrm{t}\left(\alpha_{0}=0\right)$ & $\alpha_{\mathrm{J}}$ & $\mathrm{t}\left(\alpha_{\mathrm{J}}=0\right)$ \\
\hline $1962-2001$ & -0.00007 & -0.92 & 0.00641 & 9.87 \\
$1962-1979$ & 0.00009 & 0.97 & 0.00815 & 7.14 \\
$1980-1989$ & -0.00014 & -0.73 & 0.00433 & 4.55 \\
$1990-2001$ & -0.00026 & -1.72 & 0.00565 & 5.37 \\
\hline
\end{tabular}

\section{The Weekend Effect}

French (1980) observed another calendar anomaly. He noted that the average return to the Standard \& Poor's (S\&P) composite portfolio was reliably negative over weekends in the period 1953-1977. Table 3 shows estimates of the weekend effect from February 1885 to May 2002, as well as for the 1953-1977 period analyzed by French (1980) and the 1885-1927, 19281952, and 1978-2002 sample periods not included in French's study. The dependent variable is the daily return to a broad portfolio of U.S. stocks. For the 1885-1927 period, the Schwert (1990) portfolio based on Dow Jones indexes is used. For 1928-2002, the S\&P composite 
portfolio is used. The independent variable, Weekend, equals one when the daily return spans a weekend (e.g., Friday to Monday), and zero otherwise. Thus, the coefficient $\alpha_{\mathrm{W}}$ measures the difference between the average daily return over weekends and the other days of the week. If weekend returns are reliably lower than returns on other days of the week, $\alpha_{W}$ should be reliably negative (and the sum of $\alpha_{0}+\alpha_{\mathrm{W}}$ should be reliably negative to confirm French's (1980) results).

The results for 1953-1977 replicate the results in French (1980). The estimate of the weekend effect for 1928-1952 is even more negative, as previously noted by Keim and Stambaugh (1984). The estimate of the weekend effect from 1885-1927 is smaller, about half the size for 1953-1977 and about one-third the size for 1928-1952, but still reliably negative. Interestingly, the estimate of the weekend effect since 1978 is not reliably different from the other days of the week. While the point estimate of $\alpha_{\mathrm{W}}$ is negative from 1978-2002, it is about one-quarter as large as the estimate for 1953-1977, and it is not reliably less than zero. The estimate of the average return over weekends is the sum $\alpha_{0}+\alpha_{\mathrm{W}}$, which is essentially zero for 1978-2002.

Thus, like the size effect, the weekend effect seems to have disappeared, or at least substantially attenuated, since it was first documented in 1980.

\section{The Value Effect}

Around the same time as early size effect papers, Basu $(1977,1983)$ noted that firms with high earnings-to-price $(\mathrm{E} / \mathrm{P})$ ratios earn positive abnormal returns relative to the CAPM. Many subsequent papers have noted that positive abnormal returns seem to accrue to portfolios of stocks with high dividend yields $(\mathrm{D} / \mathrm{P})$ or to stocks with high book-to-market $(\mathrm{B} / \mathrm{M})$ values. 
Table 3

\section{Day-of-the-Week Effects in the U.S. Stock Returns, February 1885 - May 2002}

$$
\mathrm{R}_{\mathrm{t}}=\alpha_{0}+\alpha_{\mathrm{W}} \text { Weekend }_{\mathrm{t}}+\varepsilon_{\mathrm{t}}
$$

Weekend $=1$ when the return spans Sunday (e.g., Friday to Monday), and zero otherwise. The coefficient of Weekend measures the difference in average return over the weekend versus other days of the week. From 1885-1927, Dow Jones portfolios are used (see Schwert (1990)). From 1928-May 2002, the Standard \& Poor's composite portfolio is used. Heteroskedasticityconsistent standard errors are used to compute the t-statistics.

\begin{tabular}{lcccc}
\hline Sample Period & $\alpha_{0}$ & $\mathrm{t}\left(\alpha_{0}=0\right)$ & $\alpha_{\mathrm{W}}$ & $\mathrm{t}\left(\alpha_{\mathrm{W}}=0\right)$ \\
\hline $1885-2002$ & 0.0005 & 8.52 & -0.0017 & -10.13 \\
$1885-1927$ & 0.0004 & 4.46 & -0.0013 & -4.96 \\
$1928-1952$ & 0.0007 & 3.64 & -0.0030 & -6.45 \\
$1953-1977$ & 0.0007 & 6.80 & -0.0023 & -8.86 \\
$1978-2002$ & 0.0005 & 4.00 & -0.0005 & -1.37 \\
\hline
\end{tabular}

Ball (1978) made the important observation that such evidence was likely to indicate a fault in the CAPM rather than market inefficiency, because the characteristics that would cause a trader following this strategy to add a firm to his or her portfolio would be stable over time and easy to observe. In other words, turnover and transactions costs would be low and information collection costs would be low. If such a strategy earned reliable "abnormal" returns, it would be available to a large number of potential arbitrageurs at a very low cost.

More recently, Fama and French $(1992,1993)$ have argued that size and value (as measured by the book-to-market value of common stock) represent two risk factors that are 
missing from the CAPM. In particular, they suggest using regressions of the form:

$$
\left(\mathrm{R}_{\mathrm{it}}-\mathrm{R}_{\mathrm{ft}}\right)=\alpha_{\mathrm{i}}+\beta_{\mathrm{i}}\left(\mathrm{R}_{\mathrm{mt}}-\mathrm{R}_{\mathrm{ft}}\right)+\mathrm{s}_{\mathrm{i}} \mathrm{SMB}_{\mathrm{t}}+\mathrm{h}_{\mathrm{i}} \mathrm{HML}_{\mathrm{t}}+\varepsilon_{\mathrm{it}}
$$

to measure abnormal performance, $\alpha_{\mathrm{i}}$. In (2), SMB represents the difference between the returns to portfolios of small- and large-capitalization firms, holding constant the $\mathrm{B} / \mathrm{M}$ ratios for these stocks, and HML represents the difference between the returns to portfolios of high and low B/M ratio firms, holding constant the capitalization for these stocks. Thus, the regression coefficients $s_{i}$ and $h_{i}$ represent exposures to size and value risk in much the same way that $\beta_{i}$ measures the exposure to market risk.

Fama and French (1993) used their three-factor model to explore several of the anomalies that have been identified in earlier literature, where the test of abnormal returns is based on whether $\alpha_{i}=0$ in (2). They found that abnormal returns from the three-factor model in (2) are not reliably different from zero for portfolios of stocks sorted by: equity capitalization, B/M ratios, dividend yield, or earnings-to-price ratios. The largest deviations from their three-factor model occur in the portfolio of low B/M (i.e., growth) stocks, where small-capitalization stocks have returns that are too low and large-capitalization stocks have returns that are too high $\left(\alpha_{i}>\right.$ $0)$.

Fama and French (1996) extended the use of their three-factor model to explain the anomalies studied by Lakonishok, Shleifer, and Vishny (1994). They found no estimates of abnormal performance in (2) that are reliably different from zero based on variables such as $\mathrm{B} / \mathrm{M}, \mathrm{E} / \mathrm{P}$, cash flow over price $(\mathrm{C} / \mathrm{P})$, and the rank of past sales growth rates.

In 1993, Dimensional Fund Advisors (DFA) began a mutual fund that focuses on small firms with high $\mathrm{B} / \mathrm{M}$ ratios (the DFA US 6-10 Value Portfolio). Based on the results in Fama and French (1993), this portfolio would have earned significantly positive "abnormal" returns of 
about $0.5 \%$ per month over the period 1963-1991 relative to the CAPM. The estimate of the abnormal return to the DFA Value portfolio from 1994-2002 in the last row of Table 1 is $-0.2 \%$ per month, with a t-statistic of -0.59 . Thus, as with the DFA US 9-10 Small Company Portfolio, the apparent anomaly that motivated the fund's creation seems to have disappeared, or at least attenuated.

Davis, Fama, and French (2000) collected and analyzed B/M data from 1929 through 1963 to study a sample that does not overlap the data studied in Fama and French (1993). They found that the apparent premium associated with value stocks is similar in the pre-1963 data to the post-1963 evidence. They also found that the size effect is subsumed by the value effect in the earlier sample period. Fama and French (1998) have shown that the value effect exists in a sample covering 13 countries (including the U.S.) over the period 1975-1995. Thus, in samples that pre-date the publication of the original Fama and French (1993) paper, the evidence supports the existence of a value effect.

Daniel and Titman (1997) have argued that size and M/B characteristics dominate the Fama-French size and $\mathrm{B} / \mathrm{M}$ risk factors in explaining the cross-sectional pattern of average returns. They conclude that size and $\mathrm{M} / \mathrm{B}$ are not risk factors in an equilibrium pricing model. However, Davis, Fama, and French (2000) found that Daniel and Titman's results do not hold up outside their sample period.

\section{The Momentum Effect}

Fama and French (1996) have also tested two versions of momentum strategies. DeBondt and Thaler (1985) found an anomaly whereby past losers (stocks with low returns in the past three to five years) have higher average returns than past winners (stocks with high returns in the past three to five years), which is a "contrarian" effect. On the other hand, 
Jegadeesh and Titman (1993) found that recent past winners (portfolios formed on the last year of past returns) out-perform recent past losers, which is a "continuation" or "momentum" effect. Using their three-factor model in (2), Fama and French found no estimates of abnormal performance that are reliably different from zero based on the long-term reversal strategy of DeBondt and Thaler (1985), which they attribute to the similarity of past losers and small distressed firms. On the other hand, Fama and French are not able to explain the short-term momentum effects found by Jegadeesh and Titman (1993) using their three-factor model. The estimates of abnormal returns are strongly positive for short-term winners.

Table 4 shows estimates of the momentum effect using both the CAPM benchmark in (1) and the Fama-French three-factor benchmark in (2). The measure of momentum is the difference between the returns to portfolios of high and low prior return firms, UMD, where prior returns are measured over months -2 to -13 relative to the month in question. ${ }^{5}$ The sample periods shown are the 1965-1989 period used by Jegadeesh and Titman (1993), the 1927-1964 period that preceded their sample, the 1990-2001 period that occurred after their paper was published, and the overall 1927-2001 period. Compared with the CAPM benchmark in the top panel of Table 4, the momentum effect seems quite large and reliable. The intercept $\alpha$ is about $1 \%$ per month, with t-statistics between 2.7 and 7.0. In fact, the smallest estimate of abnormal returns occurs in the 1965-1989 period used by Jegadeesh and Titman (1993) and the largest estimate occurs in the 1990-2001 sample after their paper was published. ${ }^{6}$

\footnotetext{
${ }^{5}$ This Fama-French momentum factor for the period 1927-2001 is available from Ken French's web site, http://mba.tuck.dartmouth.edu/pages/faculty/ken.french/ftp/F-F_Momentum_Factor.zip.

${ }^{6}$ Jegadeesh and Titman (2001) also show that the momentum effect remains large in the post 1989 period. They tentatively conclude that momentum effects may be related to behavioral biases of investors.
} 


\section{Table 4}

\section{Momentum Effects, 1927 - 2001 \\ $\mathrm{UMD}_{\mathrm{t}}=\alpha+\beta\left(\mathrm{R}_{\mathrm{mt}}-\mathrm{R}_{\mathrm{ft}}\right)+\mathrm{s} \mathrm{SMB}_{\mathrm{t}}+\mathrm{hHML}+\varepsilon_{\mathrm{t}}$}

$\mathrm{UMD}_{\mathrm{t}}$ is the return to a portfolio that is long stocks with high returns and short stocks with low returns in recent months (months -13 through -2 ). The market risk premium is measured as the difference in return between the CRSP value-weighted portfolio of NYSE, Amex and Nasdaq stocks $\left(\mathrm{R}_{\mathrm{m}}\right)$ and the one-month Treasury bill yield $\left(\mathrm{R}_{\mathrm{f}}\right)$. $\mathrm{SMB}_{\mathrm{t}}$ is the difference between the returns to portfolios of small- and largecapitalization firms, holding constant the $\mathrm{B} / \mathrm{M}$ ratios for these stocks, and $\mathrm{HML}_{\mathrm{t}}$ is the difference between the returns to portfolios of high and low B/M ratio firms, holding constant the capitalization for these stocks. Heteroskedasticity-consistent standard errors are used to compute the t-statistics.

\begin{tabular}{|c|c|c|c|c|c|c|c|c|c|}
\hline $\begin{array}{c}\text { Sample } \\
\text { Period }\end{array}$ & $\begin{array}{l}\text { Sample } \\
\text { Size, T }\end{array}$ & $\alpha$ & $\mathrm{t}(\alpha=0)$ & $\beta$ & $\mathrm{t}(\beta=0)$ & $\mathrm{s}$ & $\mathrm{t}(\mathrm{s}=0)$ & $\mathrm{h}$ & $\mathrm{t}(\mathrm{h}=0)$ \\
\hline \multicolumn{10}{|c|}{ Single-Factor CAPM Benchmark } \\
\hline $\begin{array}{l}1926- \\
2001\end{array}$ & 900 & 0.0095 & 6.98 & -0.280 & -3.48 & & & & \\
\hline $\begin{array}{l}1926- \\
1964\end{array}$ & 456 & 0.0100 & 5.33 & -0.415 & -4.06 & & & & \\
\hline $\begin{array}{l}1965- \\
1989\end{array}$ & 300 & 0.0082 & 4.00 & 0.016 & 0.22 & & & & \\
\hline $\begin{array}{l}1926- \\
1989\end{array}$ & 756 & 0.0091 & 6.37 & -0.303 & -3.50 & & & & \\
\hline $\begin{array}{l}1990- \\
2001\end{array}$ & 144 & 0.0107 & 2.71 & -0.063 & -0.56 & & & & \\
\hline
\end{tabular}

Three-Factor Fama-French Benchmark

\begin{tabular}{llllllllll}
\hline $1926-$ & 900 & 0.0110 & 8.25 & -0.193 & -3.75 & -0.102 & -1.14 & -0.484 & -4.65 \\
2001 & & & & & & & & & \\
$1926-$ & 456 & 0.0103 & 5.72 & -0.204 & -3.45 & -0.137 & -0.95 & -0.525 & -3.67 \\
1964 & & & & & & & & & \\
$1965-$ & 300 & 0.0100 & 4.61 & -0.010 & -0.13 & -0.132 & -1.17 & -0.276 & -2.08 \\
1989 & & & & & & & & & \\
$1926-$ & 756 & 0.0107 & 7.77 & -0.170 & -3.27 & -0.128 & -1.25 & -0.519 & -4.50 \\
1989 & & & & & & & & & \\
$1990-$ & 144 & 0.0123 & 2.95 & -0.201 & -1.83 & 0.093 & 0.54 & -0.245 & -1.35 \\
2001 & & & & & & & & & \\
\hline
\end{tabular}


Fama and French (1996) noted that their three-factor model does not explain the momentum effect, since the intercepts in the bottom panel of Table 4 are all reliably positive. In fact, the intercepts from the three-factor models are larger than from the single-factor CAPM model in the upper panel.

Lewellen (2002) has presented evidence that portfolios of stocks sorted on size and B/M characteristics have similar momentum effects as those seen by Jegadeesh and Titman (1993, 2001) and Fama and French (1996). He argues that the existence of momentum in large diversified portfolios makes it unlikely that behavioral biases in information processing are likely to explain the evidence on momentum.

Brennan, Chordia, and Subrahmanyam (1998) found that size and B/M characteristics do not explain differences in average returns, given the Fama and French three-factor model. Like Fama and French (1996), they found that the Fama-French model does not explain the momentum effect. Finally, they found a negative relation between average returns and recent past dollar trading volume. They argue that this reflects a relation between expected returns and liquidity as suggested by Amihud and Mendelson (1986) and Brennan and Subrahmanyam (1996).

Thus, while many of the systematic differences in average returns across stocks can be explained by the three-factor characterization of Fama and French (1993), momentum cannot. Interestingly, the average returns to index funds that were created to mimic the size and value strategies discussed above have not matched up to the historical estimates, as shown in Table 1. The evidence on the momentum effect seems to persist, but may reflect predictable variation in risk premiums that are not yet understood. 


\subsection{Predictable Differences in Returns Through Time}

In the early years of the efficient markets literature, the random walk model, in which returns should not be autocorrelated, was often confused with the hypothesis of market efficiency (see, for example, Black (1971)). Fama $(1970,1976)$ made clear that the assumption of constant equilibrium expected returns over time is not a part of the efficient markets hypothesis, although that assumption worked well as a rough approximation in many of the early efficient markets tests.

Since then, many papers have documented a small degree of predictability in stock returns based on prior information. Examples include Fama and Schwert (1977) [short-term interest rates], Keim and Stambaugh (1986) [spreads between high-risk corporate bond yields and short-term interest rates], Campbell (1987) [spreads between long- and short-term interest rates], French, Schwert, and Stambaugh (1987) [stock volatility], Fama and French (1988) [dividend yields on aggregate stock portfolios], and Kothari and Shanken (1997) [book-tomarket ratios on aggregate stock portfolios]. Recently, Baker and Wurgler (2000) have shown that the proportion of new securities issues that are equity issues is a negative predictor of future equity returns over the period 1928-1997.

An obvious question given evidence of the time-series predictability of returns is whether this is evidence of market inefficiency, or simply evidence of time-varying equilibrium expected returns. Fama and Schwert (1977) found weak evidence that excess returns to the CRSP valueweighted portfolio of NYSE stocks (in excess of the one-month Treasury bill yield) are predictably negative. Many subsequent papers have used similar metrics to judge whether the evidence of time variation in expected returns seems to imply profitable trading strategies. I am not aware of a paper that claims to find strong evidence that excess stock returns have been 
predictably negative, although that may be an extreme standard for defining market inefficiency since it ignores risk.

\section{$\underline{\text { Short-Term Interest Rates, Expected Inflation, and Stock Returns }}$}

Using data from 1953-1971, Fama and Schwert (1977) documented a reliable negative relation between aggregate stock returns and short-term interest rates. Since Fama (1975) had shown that most of the variation in short-term interest rates was due to variation in expected inflation rates during this period, Fama and Schwert concluded that expected stock returns are negatively related to expected inflation.

Table 5 shows estimates of the relation between stock returns and short-term interest rates or expected inflation rates for the period January 1831 - May 2002, as well as for the 19531971 period analyzed by Fama and Schwert (1977). The dependent variable $\mathrm{R}_{\mathrm{mt}}$ is the monthly return to an aggregate stock portfolio (based on the Schwert (1990) data for 1831-1925 and the CRSP value-weighted portfolio for 1926-2001, and the Standard \& Poor's composite for 2002),

$$
\mathrm{R}_{\mathrm{mt}}=\alpha+\gamma \mathrm{R}_{\mathrm{ft}}+\varepsilon_{\mathrm{t}}
$$

where $\mathrm{R}_{\mathrm{ft}}$ is the yield on a short-term low-risk security (commercial paper yields from 1831-1925 and Treasury yields from 1926-2002). ${ }^{7}$ The negative relation between expected stock returns and short-term interest rates is strongest for the 1953-1971 period, but the estimate is negative in all of the sample periods in Table 5, and it is reliably different from zero over 1831-1925. The tstatistic for $1972-2002$ is -1.08 .

It is common to use the average difference between the return from a large portfolio of stocks and the yield on a short-term bond $\left(\mathrm{R}_{\mathrm{mt}}-\mathrm{R}_{\mathrm{ft}}\right)$ as an estimate of the market risk premium

\footnotetext{
${ }^{7}$ Schwert (1989) describes the sources and methods used to derive the short-term interest rate series.
} 
(e.g., Ibbotson Associates (1998) and Brealey and Myers (2000)). This model of the market risk premium implies that the coefficient of $\mathrm{R}_{\mathrm{ft}}$ in (3) should be 1.0, so that the negative estimates are even more surprising. For example, the t-statistic for the hypothesis that the coefficient of $R_{f t}$ equals 1.0 for $1972-2002$ is -2.03 .

Table 5 also shows estimates of the relation between stock returns and two measures of the expected inflation rate, using the Consumer Price Index (CPI) and the Producer Price Index (PPI). The model for expected inflation uses a regression of the inflation rate on the short-term interest rate with $\mathrm{ARMA}(1,1)$ errors,

$$
\mathrm{PPI}_{\mathrm{t}}=\alpha_{0}+\gamma_{0} \mathrm{~TB}_{\mathrm{t}}+\left[(1-\theta \mathrm{L}) /[(1-\phi \mathrm{L})] \varepsilon_{\mathrm{t}},\right.
$$

where $\mathrm{L}$ is the lag operator, $\mathrm{L}^{\mathrm{k}} \mathrm{X}_{\mathrm{t}}=\mathrm{X}_{\mathrm{t}-\mathrm{k}}$, estimated using the most recent 120 months of data to forecast inflation in month $\mathrm{t}+1 .{ }^{8}$ It is notable that the negative relation with stock returns is stronger for the interest rate $\mathrm{R}_{\mathrm{ft}}$ than for either measure of the expected inflation rate, even though $\mathrm{R}_{\mathrm{ft}}$ is a part of the prediction model for inflation. This shows that the interest rate is not a close proxy for the expected inflation rate outside the 1953-1971 period. It also shows that the negative relation between stock returns and short-term interest rates is not always due to expected inflation.

Thus, the apparent ability of short-term interest rates to predict stock returns is strongest in the period used by Fama and Schwert (1977). Nevertheless, it does seem that excess returns on stocks are negatively related to interest rates, suggesting a slowly time-varying market risk premium. If the market risk premium varies because of underlying economic fundamentals, this is not an anomaly that would allow investors to trade to make abnormal profits.

\footnotetext{
${ }^{8}$ This model is similar the model used by Nelson and Schwert (1977) to model the CPI inflation rate from 19531977. It is a flexible model that is capable of representing a wide variety of persistence in the inflation data.
} 


\section{Table 5}

\section{Relation between Stock Market Returns and Short-Term Interest Rates or Expected Inflation, January 1831 - May 2002}

$$
\mathrm{R}_{\mathrm{mt}}=\alpha+\gamma \mathrm{X}_{\mathrm{t}}+\varepsilon_{\mathrm{t}}
$$

$\mathrm{X}_{\mathrm{t}}=\mathrm{R}_{\mathrm{ft}}, \mathrm{E}\left(\mathrm{PPI}_{\mathrm{t}}\right)$, or $\mathrm{E}\left(\mathrm{CPI}_{\mathrm{t}}\right)$. $\mathrm{R}_{\mathrm{ft}}$ is the yield on a one-month security (commercial paper from 1831-1925 and Treasury securities from 1926-2002). E(PPI $\left.{ }_{t}\right)$ is the one-month-ahead forecast from a predictive model for PPI inflation:

$$
\mathrm{PPI}_{\mathrm{t}}=\alpha_{0}+\gamma_{0} \mathrm{R}_{\mathrm{ft}}+\left[(1-\theta \mathrm{L}) /[(1-\phi \mathrm{L})] \varepsilon_{\mathrm{t}}\right.
$$

which is a regression of PPI inflation on the short-term interest rate with $\operatorname{ARMA}(1,1)$ errors estimated with the prior 120 months of data. Similarly, E(CPI $)$ is the one-month-ahead forecast from a predictive model for CPI inflation. Heteroskedasticity-consistent t-statistics are in parentheses under the coefficient estimates.

\begin{tabular}{cccc}
\hline $\begin{array}{c}\text { Sample Period } \\
\text { (Sample Size) }\end{array}$ & $\mathrm{R}_{\mathrm{ft}}$ & $\mathrm{E}\left(\mathrm{PPI}_{\mathrm{t}}\right)^{\mathrm{a}}$ & $\mathrm{E}(\mathrm{CPI})_{\mathrm{t}}{ }^{\mathrm{b}}$ \\
\hline $1831-2002$ & -2.073 & 0.139 & -0.591 \\
$(2,053)$ & $(-3.50)$ & $(0.93)$ & $(-0.68)$ \\
$1831-1925$ & -3.958 & 0.223 & \\
$(1,136)$ & $(-4.58)$ & $(1.53)$ & -0.580 \\
$1926-1952$ & 0.114 & -0.056 & $(-0.46)$ \\
$(324)$ & $(0.03)$ & $(-0.10)$ & -2.448 \\
$1953-1971$ & -5.559 & -0.412 & $(-1.13)$ \\
$(228)$ & $(-2.57)$ & $(-0.43)$ & -1.258 \\
$1972-2002$ & -1.140 & -0.612 & $(-1.29)$ \\
$(357)$ & $(-1.08)$ & $(-0.95)$ & \\
\hline
\end{tabular}

${ }^{a} 120$ PPI observations are used to create the forecasting model, so the sample size from 1831-2002 is 1,932 and from $1831-1925$ it is 1,015 .

${ }^{b}$ CPI data are available from 1913-2002, and 120 observations are used to create the forecasting model, so the sample size from 1831-2002 is 952 . 


\section{Dividend Yields and Stock Returns}

Using CRSP data for the period 1927-1986, Fama and French (1988) showed that aggregate dividend yields predict subsequent stock returns. Many subsequent papers have amplified this finding and several have questioned aspects of the statistical procedures used, including Goyal and Welch (1999). Table 6 reproduces some of the main results from Fama and French (1988), but also uses the Cowles (1939) data for 1872-1926 and additional CRSP data for 1987-2000. The equation estimated by Fama and French is,

$$
r(t, t+T)=\alpha+\delta Y(t)+\varepsilon(t, t+T)
$$

where $\mathrm{Y}(\mathrm{t})=\mathrm{D}(\mathrm{t}) / \mathrm{P}(\mathrm{t}-1), \mathrm{P}(\mathrm{t})$ is the price at time $\mathrm{t}, \mathrm{D}(\mathrm{t})$ is the dividend for the year preceding $\mathrm{t}$, and $r(t, t+T)$ is the continuously compounded nominal return from $t$ to the slope estimates are much smaller and the explanatory power of the models $\left(R^{2}\right)$ is negligible. $t+T$.

What is clear from Table 6 is that the incremental data both before and after the 19271986 period studied by Fama and French shows a much weaker relation between aggregate dividend yields and subsequent stock returns. None of the t-statistics for the slope coefficient $\delta$ are larger than 2.0, even for the 1872-2000 sample which includes the 1927-1986 data used by Fama and French (about half of the sample). This occurs because the slope estimates are much smaller and the explanatory power of the models $\left(\mathrm{R}^{2}\right)$ is negligible. 


\section{Table 6}

\section{Relation between Stock Market Returns and Aggregate Dividend Yields, 1872-2000}

$$
r(t, t+T)=\alpha+\delta Y(t)+\varepsilon(t, t+T)
$$

$\mathrm{P}(\mathrm{t})$ is the price at time t. $\mathrm{Y}(\mathrm{t})$ equals either $\mathrm{D}(\mathrm{t}) / \mathrm{P}(\mathrm{t})$ or $\mathrm{D}(\mathrm{t}) / \mathrm{P}(\mathrm{t}-1)$, where $\mathrm{D}(\mathrm{t})$ is the dividend for the year preceding $t$. $r(t, t+T)$ is the continuously compounded nominal return from to $t+T$ to the CRSP value-weighted portfolio from 1926-2000 and to the Cowles portfolio from 18721925. The regressions for two-, three- and four-year returns use overlapping annual observations. The $\mathrm{t}$-statistics $\mathrm{t}(\delta)$ use heteroskedasticity- and autocorrelation-consistent standard error estimates. $\mathrm{R}^{2}$ is the coefficient of determination, adjusted for degrees of freedom, and $\mathrm{S}(\varepsilon)$ is the standard error of the regression.

\begin{tabular}{|c|c|c|c|c|c|c|c|c|}
\hline \multirow{2}{*}{$\begin{array}{c}\text { Return } \\
\text { horizon, } \\
\mathrm{T}\end{array}$} & \multicolumn{4}{|c|}{$\mathrm{Y}(\mathrm{t})=\mathrm{D}(\mathrm{t}) / \mathrm{P}(\mathrm{t})$} & \multicolumn{4}{|c|}{$\mathrm{Y}(\mathrm{t})=\mathrm{D}(\mathrm{t}) / \mathrm{P}(\mathrm{t}-1)$} \\
\hline & $\delta$ & $\mathrm{t}(\delta)$ & $\mathrm{R}^{2}$ & $\mathrm{~S}(\varepsilon)$ & $\delta$ & $t(\delta)$ & $\mathrm{R}^{2}$ & $\mathrm{~S}(\varepsilon)$ \\
\hline \multicolumn{9}{|c|}{$1927-1986, \mathrm{~N}=60$} \\
\hline 1 & 2.21 & 1.00 & 0.01 & 0.21 & 5.25 & 3.03 & 0.07 & 0.20 \\
\hline 2 & 6.88 & 2.78 & 0.08 & 0.30 & 8.85 & 3.53 & 0.09 & 0.29 \\
\hline 3 & 9.28 & 3.23 & 0.12 & 0.33 & 11.25 & 3.82 & 0.12 & 0.33 \\
\hline 4 & 12.05 & 4.00 & 0.16 & 0.36 & 12.55 & 4.54 & 0.12 & 0.37 \\
\hline \multicolumn{9}{|c|}{$1872-2000, \mathrm{~N}=129$} \\
\hline 1 & 0.53 & 0.52 & -0.01 & 0.18 & 1.27 & 1.16 & 0.00 & 0.18 \\
\hline 2 & 2.03 & 1.44 & 0.01 & 0.26 & 1.11 & 0.66 & -0.01 & 0.26 \\
\hline 3 & 2.30 & 1.33 & 0.00 & 0.30 & 2.17 & 1.04 & 0.00 & 0.30 \\
\hline 4 & 3.87 & 1.83 & 0.02 & 0.34 & 3.40 & 1.42 & 0.01 & 0.34 \\
\hline \multicolumn{9}{|c|}{$1872-1926, N=55$} \\
\hline 1 & 0.84 & 0.64 & -0.01 & 0.16 & 0.55 & 0.29 & -0.02 & 0.16 \\
\hline 2 & 2.29 & 1.20 & 0.00 & 0.22 & -1.14 & -0.47 & -0.02 & 0.22 \\
\hline 3 & 1.49 & 0.70 & -0.01 & 0.24 & 1.16 & 0.42 & -0.02 & 0.24 \\
\hline 4 & 3.51 & 1.40 & 0.01 & 0.28 & 4.48 & 1.39 & 0.01 & 0.28 \\
\hline
\end{tabular}


Fig. 1 illustrates the limitations of the dividend yield model for predicting stock returns. Fig. 1a shows the predictions of stock returns from the model based on lagged dividend yield, $\mathrm{D}(\mathrm{t}) / \mathrm{P}(\mathrm{t}-1)$, for a one-year horizon based on estimates for 1927-1986 (the top row in the righthand panel of Table 6). It also shows the one-year return to short-term commercial paper and Treasury securities. The model for 1927-1986 is used to predict stock returns both before and after the estimation sample, for the $1872-2000$ period. Until 1961, the predicted stock return is always higher than the interest rate. However, starting in 1990, the predicted stock return is always below the interest rate. ${ }^{9}$

Fig. 1b shows the investment results that would have occurred from following a strategy of investing in short-term bonds, rather than stocks, when the dividend yield model in Table 6 predicts stock returns lower than interest rates. Both that strategy and a benchmark buy-and-hold strategy start with a $\$ 1,000$ investment in 1872 . By the end of 1999 , the buy-and-hold strategy is worth almost $\$ 6.7$ million, whereas the dividend yield asset allocation strategy is worth just over $\$ 2.2$ million. This large difference reflects the high stock returns during the 1990 s when the dividend yield model would have predicted low stock returns. In short, the out-of-sample prediction performance of this model would have been disastrous. ${ }^{10}$

In Chapter 20, Cochrane discusses return predictability in returns in relation to various indicators, such as yield spreads, dividend yields, and momentum. Again, if market returns vary because of underlying economic fundamentals, this is not an anomaly that would allow investors to trade to make abnormal profits.

\footnotetext{
${ }^{9}$ Campbell and Shiller (1998) also stress the pessimistic implications of low aggregate dividend yields and apparently followed the advice of their model (Wall Street Journal, January 13, 1997).

${ }^{10}$ Of course, it is possible that a less extreme asset allocation model that reduced exposure to stocks when dividend yields were low relative to interest rates would perform better.
} 


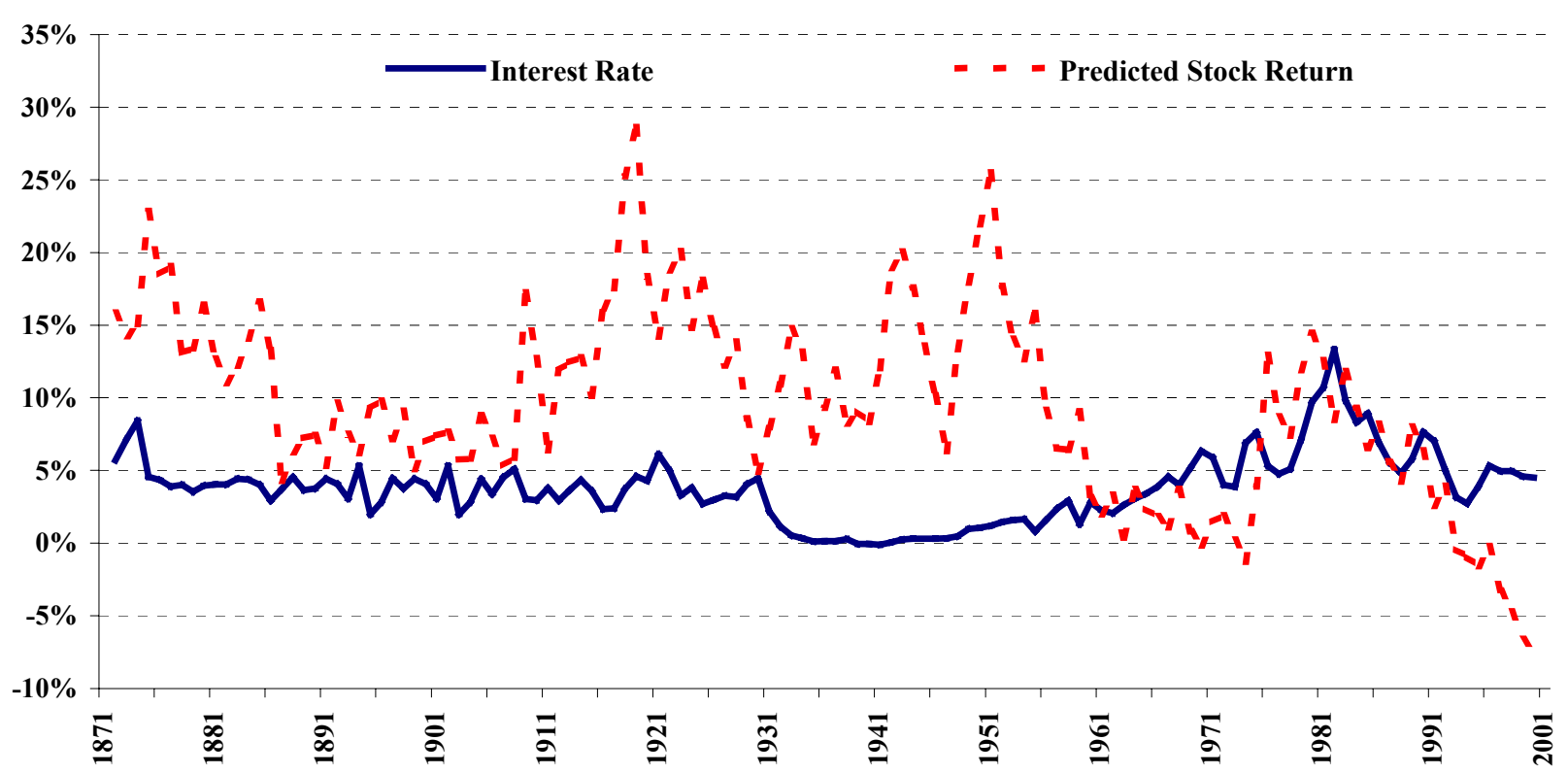

Fig 1a. Predictions of stock returns based on lagged dividend yields, $\mathrm{D}(\mathrm{t}) / \mathrm{P}(\mathrm{t}-1)$, and the regression sample from 1927-1986 versus interest rates, 1872-2000.

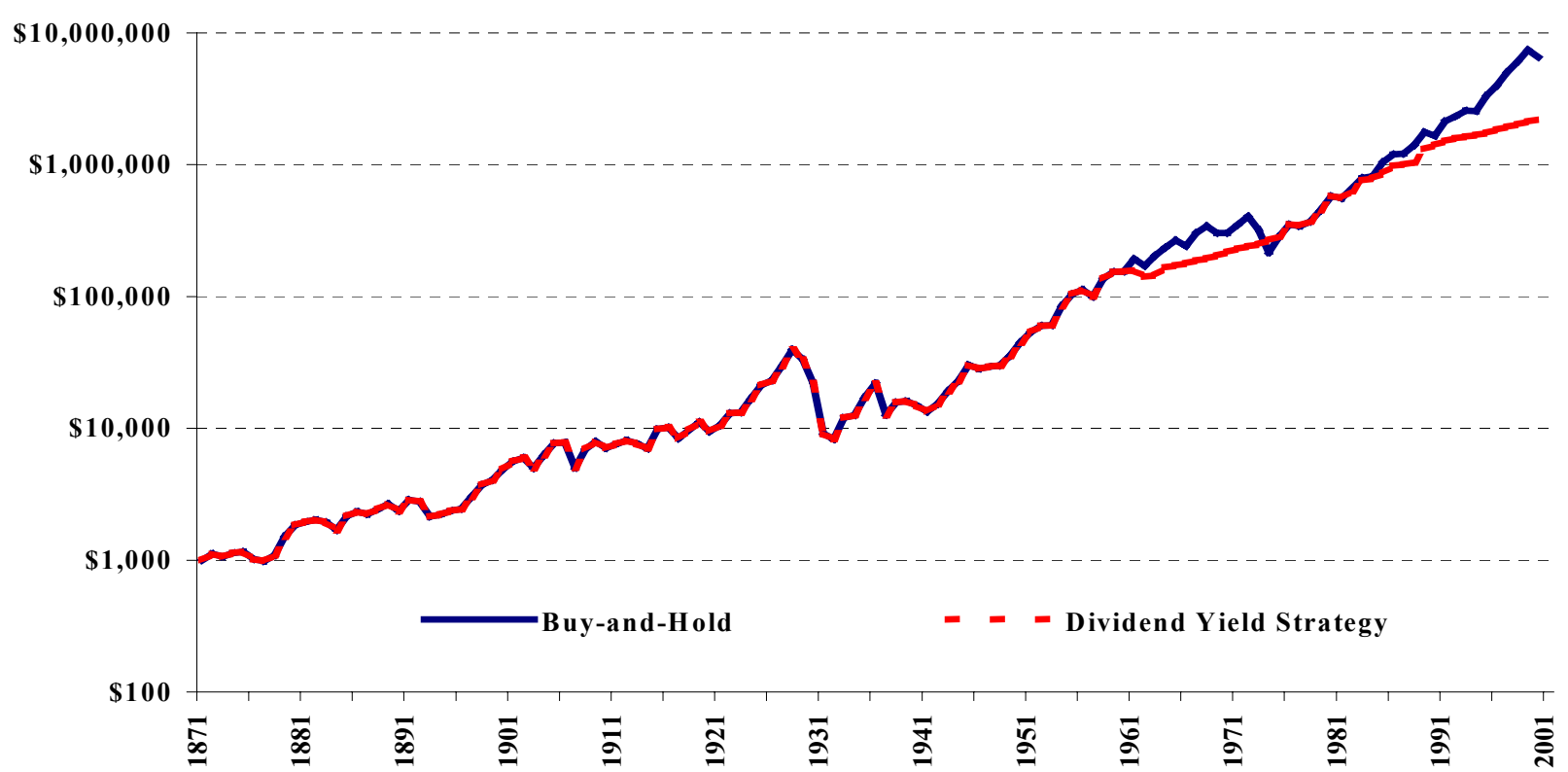

Fig 1b. Value of \$1 invested in stocks ("buy-and-hold") versus a strategy based on predictions of stock returns from a regression on lagged dividend yields, $\mathrm{D}(\mathrm{t}) / \mathrm{P}(\mathrm{t}-1)$, from 1927-1986. When predicted stock returns exceed interest rates, invest in stocks for that year. When predicted stock returns are below interest rates, invest in short-term money market instruments, 1872-2000. 


\section{Returns to Different Types of Investors}

\subsection{Individual Investors}

One simple corollary of the efficient markets hypothesis is that uninformed investors should be able to earn "normal" rates of return. It should be just as hard to select stocks that will under-perform as to select stocks that will out-perform the market, otherwise, a strategy of shortselling or similarly taking opposite positions would earn above-normal returns. Of course, investors who trade too much and incur unnecessary and unproductive transactions costs should earn below-normal returns net of these costs.

Odean (1999) examined data from 10,000 individual accounts randomly selected from a large national discount brokerage firm for the period 1987-1993. This sample covers over 160,000 trades. Because the data source is a discount brokerage firm, recommendations from a retail broker are presumably not the source of information used by investors to make trading decisions. Odean found that traders lower their returns through trading, even ignoring transactions costs, because the stocks they sell earn higher subsequent returns than the stocks they purchase.

Barber and Odean $(2000,2001)$ used different data from the same discount brokerage firm and found that active trading accounts earn lower risk-adjusted net returns than less-active accounts. They have also found that men trade more actively than women and thus earn lower risk-adjusted net returns and that the stocks that individual investors buy subsequently underperform the stocks that they sell.

The results in these papers are anomalies, but not because trading costs reduce net returns, or because men trade more often than women. They are anomalies because it seems that these individual investors can identify stocks that will systematically under-perform the Fama- 
French three-factor model in (2). One potential clue in Odean (1999) is that these investors tend to sell stocks that have risen rapidly in the recent weeks, suggesting that the subsequent good performance of these stocks is due to the momentum effect described earlier. By going against momentum, these individual investors may be earning lower returns.

\section{Closed-End Funds}

The closed-end fund puzzle has been recognized for many years. Closed-end funds generally trade in organized secondary trading markets, such as the NYSE. Since marketable securities of other firms constitute most of the assets of closed-end funds, it is relatively easy to observe both the value of the stock of the closed-end fund and the value of its assets. On average, in most periods, the fund trades at less than the value of its underlying assets, which leads to the "closed-end fund discount" anomaly.

Thompson (1978) was one of the first to carefully show that closed-end fund discounts could be used to predict above-normal returns to the shares of closed-end funds. Lee, Shleifer, and Thaler (1991) argued that the time-series behavior of closed-end fund discounts is driven by investor sentiment, with discounts shrinking when individual investors are optimistic. They found that discounts shrink at the same time that returns to small-capitalization stocks are relatively high.

Pontiff (1995) updated and extended Thompson's tests and found that the abnormal returns to closed-end funds are due to mean reversion in the discount, not to unusual returns to the assets held by the funds. In other words, when the prices of closed-end fund shares depart too much from their asset values, the difference tends to grow smaller, leading to higher-thanaverage returns to these shares.

Since the anomaly here pertains to the prices of the closed-end fund shares, not to the 
underlying investment portfolios, and since closed-end fund shares are predominantly held by individual investors, this evidence sheds light on the investment performance of some individual investors.

\subsection{Institutional Investors}

Studies of the investment performance of institutional investors date back at least to Cowles (1933). Cowles concluded that professional money managers did not systematically outperform a passive index fund strategy (although he did not use the term "index fund"). There is an extensive literature studying the returns to large samples of open-end mutual funds and, more recently, to private hedge funds.

\section{$\underline{\text { Mutual Funds }}$}

Hendricks, Patel, and Zeckhauser (1993) have found short-run persistence in mutual fund performance, although the strongest evidence is of a "cold-hands" phenomenon whereby poor performance seems more likely to persist than would be true by random chance.

Malkiel (1995) studied a database from Lipper that includes all open-end equity funds that existed in each year of the period 1971-1991. Unlike many mutual fund databases that retroactively omit funds that go out of business or merge, Malkiel's data do not suffer from the survivorship bias stressed by Brown, Goetzmann, Ibbotson, and Ross (1992). Malkiel found that mutual funds earn gross returns that are consistent with the CAPM in equation (1) and net returns that are inferior because of the expenses of active management. He also found evidence of performance persistence for the 1970s, but not for the 1980s.

Carhart (1997) also used a mutual fund database that is free of survivorship bias and found that the persistence identified by Hendricks, Patel, and Zeckhauser (1993) is explainable by the momentum effect for individual stocks described earlier. After taking this into account, 
the only evidence of persistent performance of open-end funds is that poorly performing managers have "cold hands."

\section{Hedge Funds}

The problem of assessing performance for hedge funds is complicated by the unusual strategies used by many of these funds. Fung and Hsieh (1997) showed that hedge fund returns are not well characterized as fixed linear combinations of traditional asset classes, similar to the Fama-French three-factor model. Because of changing leverage, contingent claims, and frequent changes in investment positions, traditional fund performance measures are of dubious value.

\section{$\underline{\text { Returns to IPOs }}$}

The large returns available to investors who can purchase stocks in underwritten firmcommitment initial public offerings (IPOs) at the offering price have been the subject of many papers, dating at least to Ibbotson (1975). Most of the literature on high average initial returns to IPOs focuses on the implied underpricing of the IPO stock and the effects on the issuing firm, but this evidence has equivalent implications for abnormal profits to IPO investors. Several theories have been developed to explain the systematic underpricing of IPO stocks (see Ritter's Chapter 10). Many of these theories point to the difficulty of individual investors in acquiring the most underpriced of IPOs, which is why I include this discussion in the section under returns to institutional investors.

How large are the returns to IPO investing? Fig. 2a shows the cumulative value of a strategy of investing $\$ 1,000$ starting in January 1960 in a random sample of IPOs, selling after one month, and then re-investing in a new set of IPOs in the next month. The returns to IPOs are from Ibbotson, Ritter, and Sindelar (1994) and are updated on Jay Ritter's website [http://bear.cba.ufl.edu/ritter/ipoall.htm]. For comparison, Fig. 2a also shows the value of 
investing in the CRSP value-weighted portfolio over the same period. By December 2001, the CRSP portfolio is worth about $\$ 74,000$. On the other hand, the IPO portfolio strategy is worth over $\$ 533 \times 10^{33}$. Clearly, no one has been able to follow this strategy, or people like Bill Gates and Warren Buffet would be viewed as rank amateurs in the wealth-creation business!

What are the impediments to IPO investing as a strategy for earning abnormal returns? First, it is difficult to be included in the allocations made by the underwriters. Investment banks usually allocate shares first to large institutional customers (see, e.g., Wall Street Journal, January 27,2000 ). If the institutional customers can distinguish between deals that are more underpriced and those that are less underpriced, then the shares available to individual investors are likely to offer lower initial returns. It has also been alleged that in exchange for potential favors ("spinning"), investment banks allocate shares to preferred individual clients such as politicians, including House Speaker Thomas Foley (Wall Street Journal, July 20, 1993) and Senator Alphonse D'Amato, a prominent member of the Senate Banking Committee (Wall Street Journal, June 6,1996 ), or to the executives of private firms that are considering going public in the near future (see, e.g., Wall Street Journal, November 12, 1997). Thus, a typical individual investor would have difficulty acquiring shares in the IPOs that are most underpriced.

Second, many investment banks discourage the practice of buying shares in an IPO and then selling the shares in the secondary market ("flipping"). Forcing IPO investors to hold shares for more than a month, for example, would increase the risk and costs of pursuing the IPO strategy outlined above (although it would still seem extremely profitable). To the extent that underwriters sometimes provide informal price support in the after-market by buying shares at a price close to the IPO price, it is clear why they would want to discourage flipping when initial returns are negative. On the other hand, when the after-market price rises dramatically and 
volume is high, flipping is beneficial to the underwriter by increasing market-maker profits. It is necessary for some investors who purchased shares in the IPO to sell their shares to create a public float and therefore liquidity. Indeed, there has been recent acknowledgement that flipping is useful in helping to create liquidity (see, e.g., Wall Street Journal, February 2, 2000).

Another unusual feature of IPO returns is their apparent persistence, shown in Fig. 2b. While average IPO returns are positive in almost every month from 1960 to 2001, there seem to be very noticeable cycles in these returns, with high returns following high returns and vice versa. According to Lowry and Schwert (2002), these cycles are explained by two important factors. First, the types of firms that go public tend to be clustered in time, so that crosssectional differences in IPO returns that may be due to information asymmetry, for example, show up in average returns across IPOs. Second, the learning that occurs during the registration period (as underwriters talk to potential investors) affects IPO prices and subsequent returns for the similar-type firms that are in the IPO process at the same time, and this process usually lasts more than one month. Lowry and Schwert argue that firms cannot use the persistence in IPO returns shown in Fig. $2 b$ to optimally time their IPOs (trying to minimize initial returns). By analogy, investors cannot time their participation in the IPO market (trying to maximize their returns).

Thus, while IPOs seem to offer large abnormal returns to investors who can obtain shares in the IPO allocation, it is not clear that this is an anomaly that can benefit most investors. 


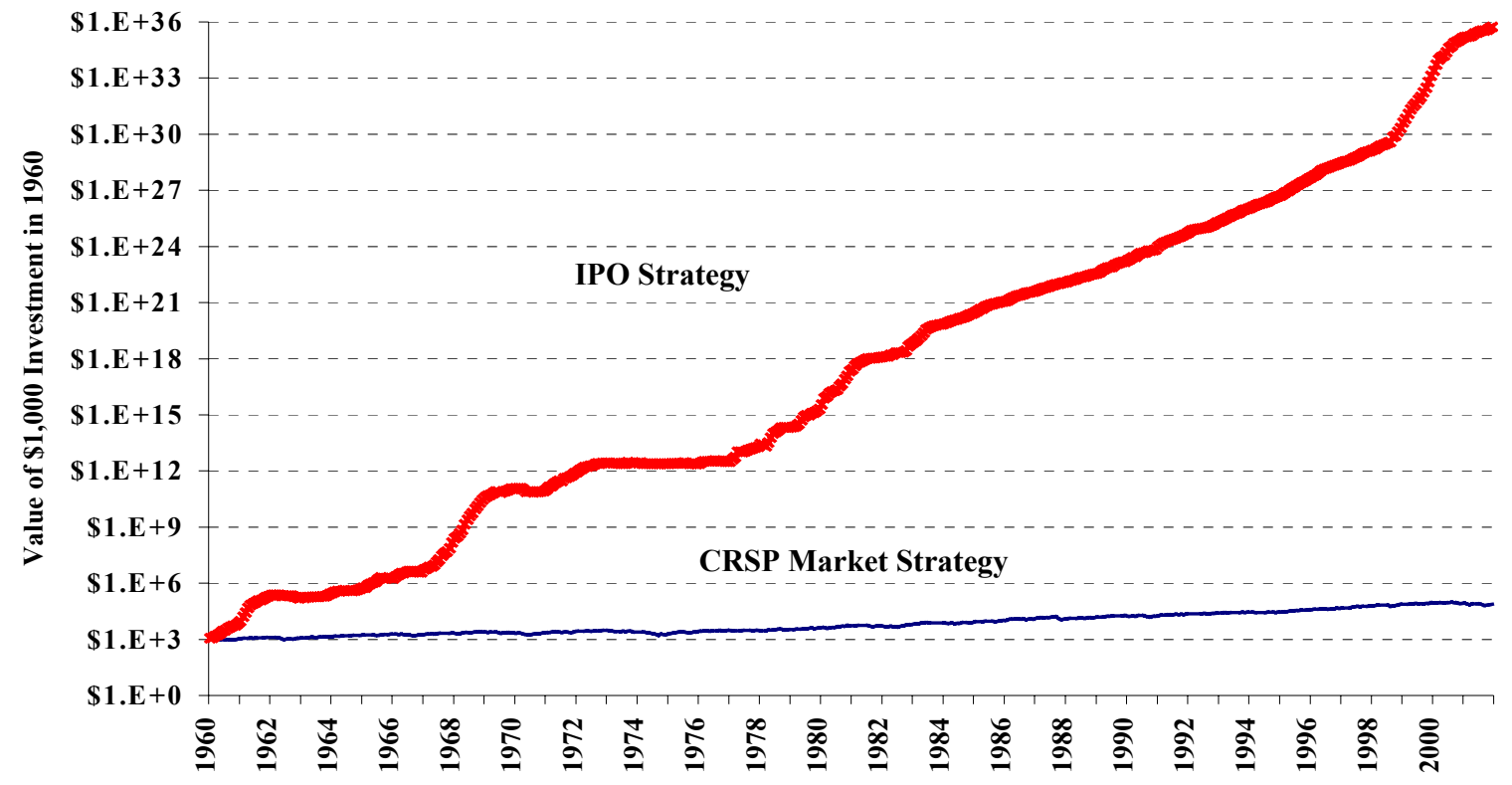

Fig. 2a. Value each month of $\$ 1,000$ invested in January 1960 in a random sample of IPOs. At the end of each month, the IPO stocks are sold and the proceeds invested in a new sample of IPOs in the next month. The scale is logarithmic and the December 2001 value of the IPO Strategy is over $\$ 533 \times 10^{33}$. For comparison, the strategy of investing $\$ 1,000$ in the CRSP valueweighted market portfolio in January 1960 is worth almost \$74,000 by December 2001.

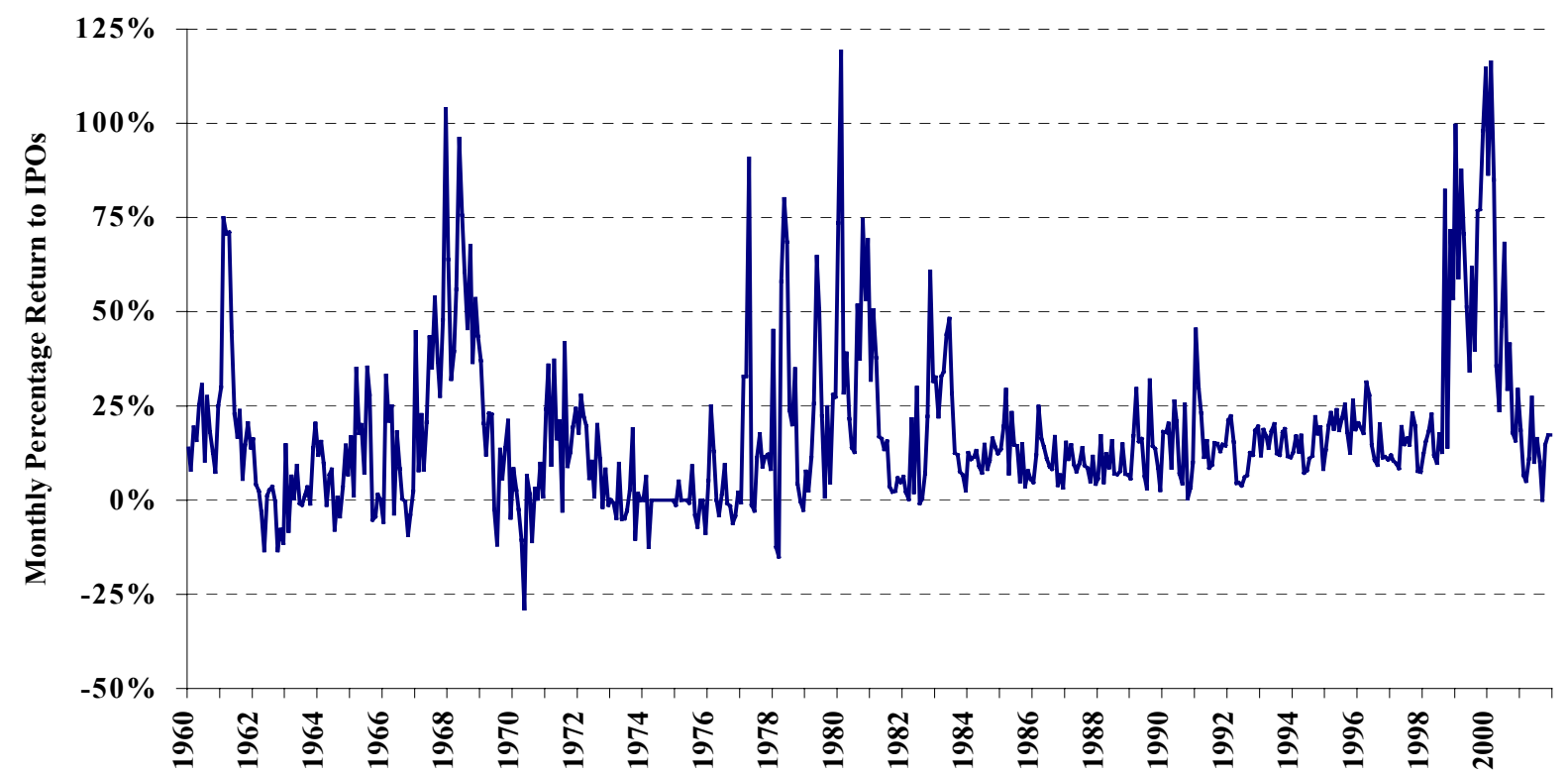

Fig. 2b. Ibbotson, Sindelar, and Ritter's (1994) monthly data on the average initial returns to IPO investors, January 1960 to December 2001. 


\subsection{Limits to Arbitrage}

It has long been recognized that transactions costs can limit the ability of traders to profit from mispricing (e.g., Jensen (1978)). The question of how market frictions affect asset prices and allow apparent anomalies to persist has received increasing attention in recent years.

Shleifer and Vishny (1997) have argued that agency problems associated with professional money managers, along with transactions costs, can cause mispricing to persist and that many anomalies are a result of such market frictions. Pontiff (1996) has shown that the absolute value of closed-end fund discounts and premiums are correlated with various measures of the costs of trying to arbitrage mispricing, including the composition of the funds' portfolios and the level of interest rates.

Table 7 lists nine papers that will appear in a special issue of the Journal of Financial Economics, all of which study the effects on asset prices of various kinds of frictions. Several of these papers contain evidence similar to Pontiff's in that the extent of apparent pricing anomalies is correlated with the size of transactions costs. 


\section{Table 7}

Contents of the Special Issue of the Journal of Financial Economics on the Limits to Arbitrage, Vol. 66, Nos. 2-3, November/December 2002

\begin{tabular}{|c|c|}
\hline Authors & Paper Title \\
\hline $\begin{array}{l}\text { Joseph Chen, } \\
\text { Harrison Hong, and } \\
\text { Jeremy C. Stein }\end{array}$ & Breadth of ownership and stock returns \\
\hline $\begin{array}{l}\text { Charles M. Jones and } \\
\text { Owen A. Lamont }\end{array}$ & Short sale constraints and stock returns \\
\hline $\begin{array}{l}\text { Christopher C. Geczy, } \\
\text { David K. Musto, and } \\
\text { Adam V. Reed }\end{array}$ & Stocks are special too: An analysis of the equity lending market \\
\hline Gene D'Avolio & The market for borrowing risk \\
\hline $\begin{array}{l}\text { Darrell Duffie, } \\
\text { Nicolae Garleanu, and } \\
\text { Lasse Heje Pedersen }\end{array}$ & Securities lending, shorting, and pricing \\
\hline $\begin{array}{l}\text { Dilip Abreu and } \\
\text { Markus K. Brunnermeier }\end{array}$ & Synchronization risk and delayed arbitrage \\
\hline $\begin{array}{l}\text { Denis Gromb and } \\
\text { Dimitri Vayanos }\end{array}$ & $\begin{array}{l}\text { Equilibrium and welfare in markets with financially constrained } \\
\text { arbitrageurs }\end{array}$ \\
\hline $\begin{array}{l}\text { Randolph B. Cohen, } \\
\text { Paul A. Gompers, and } \\
\text { Tuomo Vuolteenaho }\end{array}$ & $\begin{array}{l}\text { Who underreacts to cash-flow news? Evidence from trading } \\
\text { between individuals and institutions }\end{array}$ \\
\hline Arvind Krishnamurthy & The bond/old-bond spread \\
\hline
\end{tabular}




\section{Long-Run Returns}

DeBondt and Thaler (1985) tracked the returns to "winner" and "loser" portfolios for 36 months after portfolio formation and noted a slow drift upward in the cumulative abnormal returns (CARs) of loser stocks that had performed poorly in the recent past. They interpret this result as evidence of excessive pessimism following poor performance, making the stocks of loser firms profitable investments.

Ball, Kothari, and Shanken (1995) have argued that poor stock return performance will generally lead to higher leverage, because the value of the stock drops more than the value of the firm's debt. The increase in leverage should lead to higher risk and higher expected returns than would be reflected in risk estimates from a period before the drop in stock price. They have also pointed out that many of the stocks earning the highest returns have very low prices, so that microstructure effects, such as a large proportional bid-ask spread, can reduce subsequent performance by large amounts.

\section{Returns to Firms Issuing Equity}

Using both CARs and buy-and-hold abnormal returns (BHARs), Ritter (1991) measured post-IPO stock performance and concluded that IPO stocks yield below-normal returns in the 36 months following the IPO. He interpreted this result as evidence that investors become too optimistic about IPO firms, inflating the initial IPO return (from the IPO price to the secondary market trading price), and lowering subsequent returns. Loughran and Ritter (1995) extended Ritter's analysis using a sample of IPOs from 1970-1990.

Brav and Gompers (1997) and Brav, Geczy, and Gompers (2000) have studied the returns to IPO firms for the period 1975-1992 and found that underperformance is concentrated primarily in small firms with low book-to-market ratios. They argue that this is the same 
behavior as seen by Fama and French (1993) in their tests of their three-factor model and that the IPO anomaly is thus a manifestation of a general problem in pricing small firms with low bookto-market ratios. Brav, Geczy, and Gompers (2000) also studied seasoned equity offerings (SEOs) and found that momentum, in addition to the Fama-French three-factor model, helps explain the behavior of returns after SEOs. Eckbo, Masulis, and Norli (2000) have shown that the reduction in leverage that occurs when new equity is issued reduces subsequent equity risk exposure and thus contributes to the apparent unusual behavior of returns following SEOs.

Schultz (2001) used simulations to study the behavior of abnormal return measures after events that are triggered by prior stock price performance. For example, if a firm chooses to issue stock after its price has risen in the recent past, even if the stock price is fully rational, many of the popular measures of long-run abnormal returns will falsely reveal subsequent poor performance (he refers to this as 'pseudo-market timing'). The driving force behind his result is that the covariance between current excess returns and the number of future offerings is positive.

Many papers have analyzed long-run stock returns following a variety of events and a large number of papers have also analyzed the properties of these long-run stock return tests and alternative hypotheses to explain these types of results.

Fama (1998) has argued that the problem of measuring normal returns is particularly important when measuring long-run returns, because model problems that may be small in a day or a month can be compounded into larger apparent effects over three or five years. He has also argued that most papers that attribute apparent abnormal stock returns to behavioral effects are not testing a specific alternative model. Recent papers by Barberis, Shleifer, and Vishny (1998), Daniel, Hirshleifer, and Subrahmanyam (1998, 2001), and Barberis and Shleifer (2002) are examples of models that make predictions for short- and long-run stock returns from irrational 
investor behavior. At this point, however, it is unclear whether these models have refutable predictions that differ from tests that have already been performed.

Several papers have studied the statistical properties of long-run CARs and BHARs, including Barber and Lyon (1997), Kothari and Warner (1997), and Mitchell and Stafford (2000). All of these papers conclude that it is difficult to found long-run abnormal return measures that have well-specified statistical properties and reasonable power. Mitchell and Stafford (2000) argue that the calendar-time regression approach originally used by Jaffe (1974) and Mandelker (1974), and advocated by Fama (1998), provides more reliable inferences than long-run CARs or BHARs.

\section{Returns to Bidder Firms}

The returns to bidder firms' stocks provide another example of potentially anomalous post-event behavior. Since at least Asquith (1983), researchers have noted that there is a pronounced downward drift in the cumulative abnormal returns to the stocks of firms that are bidders in mergers. One interpretation of this evidence is that bidders overpay and that it takes the market some time to gradually learn about this mistake.

Schwert (1996) analyzed the returns to 790 NYSE and Amex-listed bidders for the period 1975-1991 and found a negative drift of about 7\% in the year following the announcement of the bid. He concluded, however, that the explanation for this drift is the unusually good stock return performance of the bidder firms in the period prior to the bid. To measure abnormal performance, he used a market model regression,

$$
R_{i t}=\alpha_{i}+\beta_{i} R_{m t}+\varepsilon_{i t},
$$

where $R_{i t}$ is the return to the bidder firm and $R_{m t}$ is the return to the CRSP value-weighted portfolio in period t, based on 253 daily returns in the year before the event analysis (which starts 
six months before the first bid is announced). Using the estimates of $\alpha_{\mathrm{i}}$ and $\beta_{\mathrm{i}}$, abnormal returns are estimated, averaged, and cumulated for the period from 127 trading days before the bid announcement to 253 trading days after the bid announcement,

$$
\begin{aligned}
& \varepsilon_{\mathrm{ik}}=\mathrm{R}_{\mathrm{ik}}-\alpha_{\mathrm{i}}-\beta_{\mathrm{i}} \mathrm{R}_{\mathrm{mk}} \\
& \mathrm{AR}_{\mathrm{k}}=\sum_{\mathrm{i}=1}^{790} \varepsilon_{\mathrm{ik}} \\
& \mathrm{CAR}_{\mathrm{J}}=\sum_{\mathrm{k}=-127}^{\mathrm{J}} \mathrm{AR}_{\mathrm{k}} .
\end{aligned}
$$

The dashed line in Fig. 3 represents the CAR to the bidder firms in (6). It drifts downward after the first bid announcement to about $-8 \%$ a year afterwards. The solid line in Fig. 3 represents a simple adjustment to the calculation of abnormal returns to bidders' stocks: the intercept $\alpha_{\mathrm{i}}$ is set equal to zero. This adjusted cumulative abnormal return does not have a noticeable drift in Fig. 3, which is consistent with the efficient markets hypothesis.

The adjustment eliminates the negative drift in abnormal returns because the estimated intercepts in the market model are systematically positive for bidder stocks in the year and a half before the bid, reflecting the fact that bidder firms are more likely to have recently experienced good performance, at least in terms of their stock prices. This abnormally good performance vanishes after the first bid (as it should in an efficient market). 


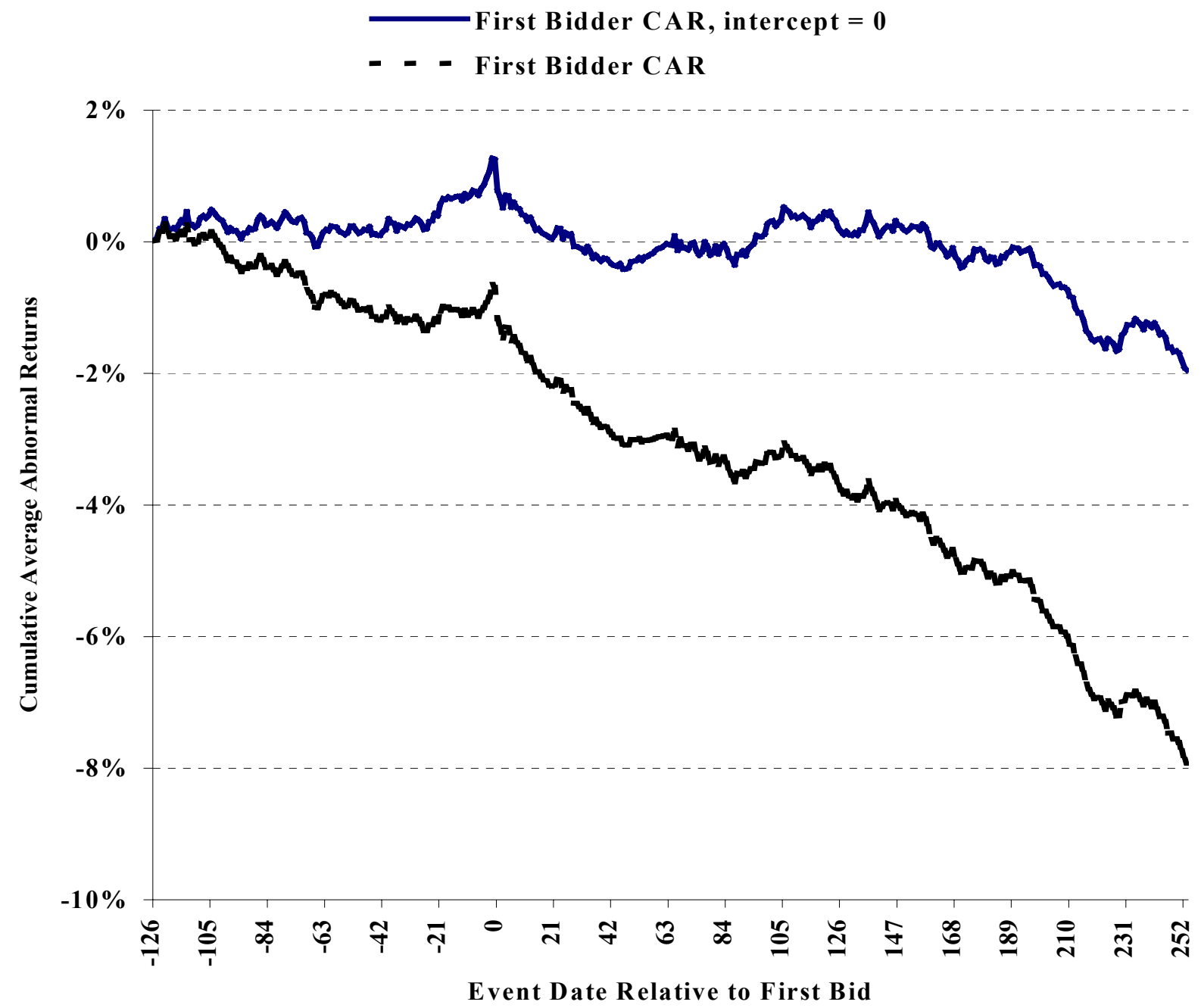

Fig. 3. Cumulative average abnormal returns to bidder firms' stocks from trading day -126 to +253 relative to the first bid for NYSE- and AMEX-listed target firms for the period 1975-1991. Market model parameters used to define abnormal returns are estimated using the CRSP valueweighted portfolio for days -379 to -127 . The solid line shows the effect of setting the intercepts to zero, since the bidder firms seem to have abnormally high stock returns during the estimation period (shown by the dotted line that drifts downward from day -126 to day +253 ). There are 790 NYSE- or Amex-listed bidder firms that made the first bid for exchange-listed target firms in this period. 
Note that this does not mean that the bid somehow caused something bad to happen to the bidder firm; it simply means that bidders' stock returns were normal in the period following the announcement of the bid. The unusually positive performance of bidders' stocks before the bid is an example of sample selection bias: the decisions of bidder firms to pursue acquisitions is correlated with their past stock price performance.

It is important to note that it is not necessary to adjust the CAR for the sample of target firms. The CAR for target firms rises gradually before the first bid announcement, reflecting bid anticipation, and jumps on the day of the announcement. After that, it remains flat for the next year. In contrast with the bidder firms, the target firms' intercepts from the estimated market models are not unusually large, reflecting neither positive nor negative stock price performance in the year and half before they become targets.

Mitchell and Stafford (2000) used the calendar-time portfolio method suggested by Fama (1998) to measure abnormal returns to acquiring firms. They concluded that an equal-weighted portfolio of acquirers seems to earn negative abnormal returns over a three-year window following an acquisition, but that a value-weighted portfolio does not, using the Fama-French three-factor model in (2) as a benchmark. This method of measuring the size and significance of abnormal returns is not affected by unusual prior performance in the same way as the CARs in Fig. 3.

Loughran and Vijh (1997) compared buy-and-hold returns to bidders' stocks measured five years after acquisitions with returns to control firms that are matched on size and book-tomarket characteristics. They found that stock mergers are followed by negative excess returns and cash tender offers are followed by positive excess returns. Since the choice of payment by the bidder is similar to a choice concerning equity financing, the sample selection issues raised 
by Schultz (2001) might affect the Loughran and Vijh (1997) results.

\section{$5 \quad$ Implications for Asset Pricing}

Consistent with Fama's observation $(1970,1976,1998)$ that tests of market efficiency are necessarily joint tests of a model of expected returns, evidence of anomalies is also potentially evidence of a short-coming in the implied asset-pricing model used for the test. One example of this phenomenon that has created much activity in the finance literature in recent years is the Fama and French (1993) three-factor model, which incorporates the size and book-to-market anomalies into the asset-pricing model.

\section{The Search for Risk Factors}

An obvious question that arises from empirically motivated adjustments of asset-pricing models is whether the new, extended model accurately describes equilibrium behavior, or is just a convenient offshoot of the anomalous findings that motivated the extension. For example, the simple two-parameter CAPM of Sharpe (1964) and Lintner (1965) was motivated by portfolio theory. Many people have developed extensions of theoretical asset-pricing models that include multiple factors (see, for example, Chapters 14 (Ross), 15 (Duffie), and 16 (Ferson)), although none of these models match closely with the empirical Fama-French model.

On the other hand, as Fama and French (1993) have pointed out, some versions of multifactor models are vague about the risk factors that might lead to differences in expected returns across assets, so that their empirical proxies (size and book-to-market) may be reflecting equilibrium trade-offs between risk and expected return. The Fama and French $(1993,1996)$ tests are consistent with their three-factor model being an adequate asset-pricing model, in the sense that the intercepts in their regression tests (measuring average abnormal returns to different 
portfolio strategies) are not reliably different from zero. ${ }^{11}$

There is at least one other issue that must be addressed, however, before concluding that the three-factor model is an accurate equilibrium-pricing model. As noted by MacKinlay (1995), the estimates of factor risk premiums from the Fama-French model seem very high, particularly for the book-to-market factor. In some ways, this is analogous to the "equity premium puzzle" that has been frequently discussed in the macro-finance literature (see Campbell's Chapter 19). If the estimates of risk premiums are too high (or too low) to be consistent with the underlying economic theory that motivates the model, the fact that average returns are linearly related to the risk factors is not sufficient to conclude that the market is efficient. If the book-to-market premium is too high, as argued by MacKinlay, then returns vary too much with this risk factor. From this perspective, the evidence that the three-factor model provides a good linear model of risk and return may be just a fortuitous description of an anomaly.

\section{Conditional Asset Pricing}

The evidence on time-varying expected returns has obvious implications for the growing literature on conditional asset-pricing models. On the other hand, the poor out-of-sample performance of some of the predictor variables raises questions about their role in asset prices.

\section{$\underline{\text { Excess Volatility }}$}

I have not addressed the question raised by Shiller (1981a,b) of whether stock market volatility is "too high." His provocative papers on "excess volatility" stimulated many rebuttals, including Kleidon (1986) and Marsh and Merton (1986), that raised questions about the validity and robustness of his statistical methods. While I have written many papers on the behavior of

\footnotetext{
${ }^{11}$ An exception is that the Fama-French (1993) portfolio of the smallest firms with the lowest book-to-market ratios has a reliably negative intercept. Also, as mentioned above, the Fama-French model does not seem to explain the momentum evidence.
} 
stock volatility, some of which raise questions about why volatility varies over time as much as it does (e.g., Schwert (1989)), I do not believe that this literature is closely linked with the literature on anomalies and market efficiency. In my 1991 review of Shiller (1989), I argue that Shiller's research on excess volatility is really a test of a particular valuation model and provides no guidance on how to identify or profit from mispricing.

\section{The Role of Behavioral Finance}

Finally, there is the issue of whether the findings in the anomalies literature can be combined with behavioral theories from the psychology literature to create new asset-pricing theories that combine economic equilibrium concepts with psychological concepts to create an improved asset-pricing model (see Chapter 18 by Barberis and Thaler). My impression, to date, is that the attempts to proceed in this direction have produced models that might explain some of the existing anomalies, but they make no predictions for observable behavior that have not already been tested extensively. ${ }^{12}$ In other words, the new behavioral theories have not yet made predictions that are refutable with new tests. Going beyond the stage of building theories to explain the "stylized facts" that already exist will be a significant challenge.

\section{Implications for Corporate Finance}

What implications do market efficiency and anomalies have for corporate finance? The standard textbook treatment of corporate finance in an efficient market (for example, Brealey and Myers (2000)) tells firms to choose projects that maximize value, and perhaps choose capital structures or dividend policies that create value, but to take the market prices of their stocks and bonds as given and more or less correct.

\footnotetext{
${ }^{12}$ Fama (1998) is less sympathetic to the ability of these new models to explain existing anomalies.
} 


\section{Firm Size and Liquidity}

How would the kinds of anomalies discussed above change this advice, if at all? To the extent that the small-firm effect is real, firms that merge and become larger would have a lower cost of capital, and therefore a higher value. But this kind of financial synergy is hard to believe. In fact, it raises the question of whether firm size somehow proxies for a more fundamental source of risk or value.

Amihud and Mendelson (1986) have argued that firm size proxies for the illiquidity of the stock and that higher transactions costs for small firms raise the required gross return so that net expected returns are equalized, given the risk of the stock. In their empirical work, they found that the cross-sectional dispersion in average returns across portfolios of NYSE stocks sorted on bid-ask spreads is similar to the dispersion in average returns across portfolios sorted on risk estimates. From this perspective, size is not a risk factor, but rather a proxy for differential transactions costs. ${ }^{13}$ Thus, actions that increase the liquidity of a firm's stock would reduce required returns and increase the stock price if such actions were costless. Decisions on whether the firm should undertake policies that increase liquidity depend on whether the benefits exceed the costs. There has been much recent work on the linkages between market microstructure, asset pricing, and corporate finance (see Chapter 21 by Easley and O'Hara).

\section{Book-to-Market Effects}

Fama and French interpret the book-to-market ratio as an indicator of "value" versus "growth" stocks, and the HML risk factor as reflecting "distress risk." In their tests, firms with high book-to-market ratios or risk sensitivities are often firms whose value has fallen recently

\footnotetext{
${ }^{13}$ The apparent disappearance of the size effect discussed in 2.1 , if true, would be problematic for the liquidity effect unless small-capitalization stocks have relatively low transaction costs in recent years.
} 
because of bad performance. These firms are more likely to suffer financial distress costs in future periods if further bad news hits.

To the extent that Fama and French (1993) are correct that SMB and HML reflect priced risk factors, then reducing a firm's exposure to these types of risk would lower the expected return on its stock, and therefore, its cost of capital. Such a change would not increase the value of the firm, however, so there is no obvious prescription for managerial behavior.

If Daniel and Titman (1997) are correct that firms with lower book-to-market ratios have lower expected returns, holding risk constant, then corporate financial policies designed to lower B/M would improve firm value by lowering the cost of capital. Of course, holding book value constant, this is equivalent to increasing the market value of the stock, which is generally good for shareholders (and not a new insight).

In the corporate finance literature, the book-to-market ratio has been interpreted as a measure of the type of investment opportunities that are available to the firm. For example, Smith and Watts (1992) have interpreted high book-to-market firms as those with "assets-inplace" and low book-to-market firms as those with relatively more "growth options." From this perspective, the fact that accounting book values make no attempt to measure the value of growth options drives the cross-sectional dispersion in book-to-market ratios. Interpreted this way, the book-to-market ratio is exogenous and reflects the investment opportunity set facing the firm. It would not make sense, for example, to advise firms to sell assets in place and invest in growth options just to lower book-to-market and, from the perspective of Daniel and Titman, to lower the cost of capital.

There has also been a substantial literature using Tobin's Q-ratio (a close relative of book-to-market) as a proxy for the efficiency with which managers use corporate assets. Dating 
back at least to Mørck, Shleifer, and Vishny (1988), high book-to-market ratios have been interpreted as indicating poor performance and possibly the existence of agency problems between stockholders and managers.

The fact that the same empirical proxy has been used in three quite different ways raises serious questions about interpreting any of this evidence in a normative way to give firms or managers advice about corporate financial policy.

\section{$\underline{\text { Slow Reaction to Corporate Financial Policy }}$}

Much of the literature studying long-horizon returns focuses on corporate financial policy decisions such as IPOs, seasoned equity offerings, share repurchases, merger bids, and so forth. A common theme in this literature is that there is a slow drift in the stock price of the firm after the event, apparently reflecting a gradual process of learning the good or bad news associated with the event. A slow reaction is inconsistent with the efficient markets hypothesis.

As mentioned above, the papers that have systematically studied the behavior of longhorizon performance measures found that they have low power and unreliable statistical properties in most situations. Even if one were to accept the premise that the market learns very slowly about the implications of changes in corporate financial policy, the uncertainty associated with the future price performance for an individual firm over a period of one to five years is so great that it would be senseless to advise that firms choose their financial policies so as to take advantage of market mispricing that is only corrected after five years.

\section{Conclusions}

This chapter highlights some interesting findings that have emerged from empirical research on the behavior of asset prices and discusses the implications of these findings for the 
way academics and practitioners use financial theory. In the process, I have replicated and extended some puzzling findings that have been called anomalies because they do not conform with the predictions of accepted models of asset pricing.

One of the interesting findings from the empirical work in this chapter is that many of the well-known anomalies in the finance literature do not hold up in different sample periods. In particular, the size effect and the value effect seem to have disappeared after the papers that highlighted them were published. At about the same time, practitioners began investment vehicles that implemented the strategies implied by the academic papers.

The weekend effect and the dividend yield effect also seem to have lost their predictive power after the papers that made them famous were published. In these cases, however, I am not aware of any practitioners who have tried to use these anomalies as a major basis of their investment strategy.

The small-firm turn-of-the-year effect became weaker in the years after it was first documented in the academic literature, although there is some evidence that it still exists. Interestingly, however, it does not seem to exist in the portfolio returns of practitioners who focus on small-capitalization firms.

Likewise, the evidence that stock market returns are predictable using variables such as dividend yields or inflation is much weaker in the periods after the papers that documented these findings were published.

All of these findings raise the possibility that anomalies are more apparent than real. The notoriety associated with the findings of unusual evidence tempts authors to further investigate puzzling anomalies and later to try to explain them. But even if the anomalies existed in the sample period in which they were first identified, the activities of practitioners who implement 
strategies to take advantage of anomalous behavior can cause the anomalies to disappear (as research findings cause the market to become more efficient). 


\section{References}

Abreu, D. and M. K. Brunnermeier (2002) "Synchronization Risk and Delayed Arbitrage," Journal of Financial Economics, 66.

Amihud, Y. and H. Mendelson (1986) “Asset Pricing and the Bid-Ask Spread," Journal of Financial Economics, 17, 223-249.

Asquith, P. (1983) "Merger Bids, Uncertainty, and Stockholder Returns," Journal of Financial Economics, 11, 51-83.

Baker, M. and J. Wurgler (2000) "The Equity Share in New Issues and Aggregate Stock Returns," Journal of Finance, 55, 2219-2257.

Ball, R. (1978) “Anomalies in Relationships Between Securities' Yields and Yield-Surrogates," Journal of Financial Economics, 6, 103-126.

Ball, R., S. P. Kothari and J. Shanken, (1995) "Problems in Measuring Portfolio Performance: An Application to Contrarian Investment Strategies," Journal of Financial Economics, 38, 79-107.

Banz, R. (1981) "The Relationship Between Return and Market Value of Common Stock," Journal of Financial Economics, 9, 3-18.

Barber, B. M. and J. D. Lyon (1997) "Detecting Long-Run Abnormal Stock Returns: Empirical Power and Specification of Test Statistics," Journal of Financial Economics, 43, 341-372.

Barber, B. M. and T. Odean (2000) "Trading Is Hazardous to Your Wealth: The Common Stock Investment Performance of Individual Investors," Journal of Finance, 55, 773-806.

Barber, B. M. and T. Odean (2001) "Boys Will Be Boys: Gender, Overconfidence, and Common Stock Investment," Quarterly Journal of Economics, 116, 261-292.

Barberis, N., A. Shleifer, and R. Vishny (1998) “A Model of Investor Sentiment," Journal of Financial Economics, 49, 307-343.

Barberis, N. and A. Shleifer (2002) “Style Investing,” Journal of Financial Economics, forthcoming.

Basu, S. (1977) "Investment Performance of Common Stocks in Relation to Their Price-Earning Ratios: A Test of the Efficient Market Hypothesis," Journal of Finance, 32, 663-682.

Basu, S. (1983) "The Relationship between Earnings' Yield, Market Value and Return for NYSE Common Stocks: Further Evidence," Journal of Financial Economics, 12, 129-156.

Black, F. (1971) “Random Walk and Portfolio Management," Financial Analyst Journal, 27, 16-22.

Booth, D. G. and D. B. Keim (2000) "Is There Still a January Effect?" in: D. B. Keim and W. T. Ziemba (eds.), Security Market Imperfections in Worldwide Equity Markets. Cambridge: Cambridge University Press, pp. 169178.

Brav, A., C. Geczy, and P. A. Gompers (2000) "Is the Abnormal Return Following Equity Issuances Anomalous?," Journal of Financial Economics, 56, 209-249.

Brav, A. and P. A. Gompers (1997) "Myth or Reality? The Long-Run Underperformance of Initial Public Offerings: Evidence from Venture and Nonventure Capital-Backed Companies," Journal of Finance, 52, 1791-1821. 
Brealey, R. A. and S. C. Myers (2000) Principles of Corporate Finance (6 $6^{\text {th }}$ ed.). New York: McGraw-Hill.

Brennan, M. J. and A. Subrahmanyam (1996) "Market Microstructure and Asset Pricing: On the Compensation for Illiquidity in Stock Returns," Journal of Financial Economics, 41, 441-464.

Brennan, M. J., T. Chordia, and A. Subrahmanyam (1998) "Alternative Factor Specifications, Security Characteristics, and the Cross-Section of Expected Stock Returns," Journal of Financial Economics, 49, 345-373.

Brown, S. J., W. Goetzmann, R. G. Ibbotson, and S. A. Ross (1992) "Survivorship Bias in Performance Studies," Review of Financial Studies, 5, 679-698.

Campbell, J. Y. (1987) “Stock Returns and the Term Structure," Journal of Financial Economics, 18, 373-400.

Campbell, J. Y. and R. J. Shiller (1998) "Valuation Ratios and the Long-Run Stock Market Outlook," Journal of Portfolio Management, 24, 11-26.

Carhart, M. M. (1997) “On the Persistence in Mutual Fund Performance,” Journal of Finance, 52, 57-82.

Chen, J., H. Hong, and J. C. Stein (2002) "Breadth of ownership and stock returns," Journal of Financial Economics, 66.

Cohen, R. B., P. A. Gompers, and T. Vuolteenaho (2002) "Who underreacts to cash-flow news? Evidence from trading between individuals and institutions," Journal of Financial Economics, 66.

Cowles, A. (1933) “Can Stock Market Forecasters Forecast?” Econometrica, 1, 309-324.

Cowles, A. (1939) Common Stock Indexes, 2nd ed., Cowles Commission Monograph no. 3, Bloomington, Indiana: Principia Press, Inc., 1939.

Daniel, K., D. Hirshleifer, A. Subrahmanyam (1998) "Investor Psychology and Security Market Under- and Overreactions," Journal of Finance, 53, 1839-1885.

Daniel, K., D. Hirshleifer, A. Subrahmanyam (2001) “Overconfidence, Arbitrage, and Equilibrium Asset Pricing," Journal of Finance, 56, 921-965.

Daniel, K., and S. Titman (1997) "Evidence on the Characteristics of Cross-Sectional Variation in Stock Returns," Journal of Finance, 52, 1-33.

Davis, J. L., E. F. Fama, and K. R. French (2000) “Characteristics, Covariances and Average Returns," Journal of Finance 55, 389-406.

D'Avolio, G. (2002) “The Market for Borrowing Stock,” Journal of Financial Economics, 66.

DeBondt, Werner F. M. and R. Thaler (1985) “Does the Stock Market Overreact?” Journal of Finance, 40, 793-805.

Duffie, D., N. Garleanu, and L. H. Pedersen (2002) "Securities Lending, Shorting, and Pricing," Journal of Financial Economics, 66.

Eckbo, B. Espen, R. W. Masulis, and Ø. Norli (2000) "Seasoned Public Offerings: Resolution of the 'New Issues Puzzle'," Journal of Financial Economics, 56, 251-291.

Fama, E. F. (1970) "Efficient Capital Markets: A Review of Theory and Empirical Work," Journal of Finance, 25, $383-417$.

Fama, E. F. (1975) "Short-Term Interest Rates as Predictors of Inflation,” American Economic Review, 65, 269-282. 
Fama, E. F. (1976) Foundations of Finance. New York: Basic Books.

Fama, E. F. (1991) “Efficient Capital Markets II,” Journal of Finance, 46, 1575-1617.

Fama, E. F. (1998) "Market Efficiency, Long-Term Returns, and Behavioral Finance," Journal of Financial Economics, 49, 283-306.

Fama, E. F. and K. R. French (1988) "Dividend Yields and Expected Stock Returns," Journal of Financial Economics, 22, 3-25.

Fama, E. F. and K. R. French (1992) “The Cross-Section of Expected Returns,” Journal of Finance, 47, 427-465.

Fama, E. F. and K. R. French (1993) "Common Risk Factors in the Returns on Stocks and Bonds," Journal of Financial Economics, 33, 3-56.

Fama, E. F. and K. R. French (1996) "Multifactor Explanations of Asset Pricing Anomalies," Journal of Finance, $51,55-84$.

Fama, E. F. and K. R. French (1998) "Value Versus Growth: The International Evidence," Journal of Finance, 53, 1975-1999.

Fama, E. F. and G. W. Schwert (1977) “Asset Returns and Inflation,” Journal of Financial Economics, 5, 115-146.

French, K. R. (1980) “Stock Returns and the Weekend Effect,” Journal of Financial Economics, 8, 55-69.

French, K. R., G. W. Schwert and R. F. Stambaugh (1987) "Expected Stock Returns and Volatility," Journal of Financial Economics, 19, 3-29.

Fung, W., and D. A. Hsieh (1997) "Empirical Characteristics of Dynamic Trading Strategies: The Case of Hedge Funds," Review of Financial Studies, 10, 275-302.

Geczy, Christopher C., D. K. Musto, and A. V. Reed (2002) "Stocks Are Special Too: An Analysis of the Equity Lending Market," Journal of Financial Economics, 66.

Goyal, A. and I. Welch (1999) "Predicting the Equity Premium,” manuscript, Yale University.

Gromb, D. and D. Vayanos (2002) "Equilibrium and Welfare in Markets with Financially Constrained Arbitrageurs," Journal of Financial Economics, 66.

Hendricks, D., J. Patel, and R. Zeckhauser (1993) "Hot Hands in Mutual Funds: Short-run Persistence of Relative Performance," Journal of Finance, 48, 93-130.

Ibbotson Associates (1998) Stocks, Bonds, Bills, and Inflation: 1998 Yearbook. Chicago: Ibbotson Associates.

Ibbotson, R. (1975) "Price Performance of Common Stock New Issues," Journal of Financial Economics, 2, 235272.

Ibbotson, R., J. Ritter, and J. Sindelar (1994) “The Market's Problem with the Pricing of Initial Public Offerings," Journal of Applied Corporate Finance, 7, 66-74.

Jaffe, J. (1974) “Special Information and Insider Trading,” Journal of Business, 47, 411-428.

Jegadeesh, N. and S. Titman (1993) "Returns to Buying Winners and Selling Losers: Implications for Stock Market Efficiency," Journal of Finance, 48, 65-91. 
Jegadeesh, N. and S. Titman (2001) "Profitability of Momentum Strategies: An Evaluation of Alternative Explanations," Journal of Finance, 56, 699-720.

Jensen, M. C. (1968) “The Performance of Mutual Funds in the Period 1945-64,” Journal of Finance, 23, 389-416.

Jensen, M. C. (1978) “Some Anomalous Evidence Regarding Market Efficiency," Journal of Financial Economics, $6,95-102$.

Jones, C. M. and O. A. Lamont (2002) "Short Sale Constraints and Stock Returns," Journal of Financial Economics, 66.

Keim, D. B. (1983) "Size-Related Anomalies and Stock Return Seasonality: Further Empirical Evidence," Journal of Financial Economics, 12, 13-32.

Keim, D. B. and R. F. Stambaugh (1984) “A Further Investigation of the Weekend Effect in Stock Returns," Journal of Finance, 39, 819-835.

Keim, D. B. and R. F. Stambaugh (1986) "Predicting Returns in the Stock and Bond Markets," Journal of Financial Economics, 17, 357-390.

Keim, D. B. and W. Ziemba (2000) "Security Market Imperfections: An Overview," in: D. B. Keim and W. T. Ziemba (eds.), Security Market Imperfections in Worldwide Equity Markets. Cambridge: Cambridge University Press, pp. xv-xxvii.

Kleidon, A. W. (1986) "Variance Bounds Tests and Stock Price Valuation Models," Journal of Political Economy, 94, 953-1001.

Kothari, S. P. and J. Shanken (1997) "Book-to-Market, Dividend Yield, and Expected Market Returns: A Time Series Analysis," Journal of Financial Economics, 44, 169-203.

Kothari, S. P. and J. B. Warner (1997) "Measuring Long-Horizon Security Price Performance," Journal of Financial Economics, 43, 301-339.

Krishnamurthy, A. (2002) “The Bond/Old-Bond Spread,” Journal of Financial Economics, 66.

Lakonishok, J., A. Shleifer and R. W. Vishny (1994) “Contrarian Investment, Extrapolation, and Risk," Journal of Finance, 49, 1541-1578.

Lee, C. M. C., A. Shleifer and R. H. Thaler (1991) "Investor Sentiment and the Closed-End Fund Puzzle," Journal of Finance, 46, 75-110.

Lewellen, J. (2002) "Momentum and Autocorrelation in Stock Returns," Review of Financial Studies, forthcoming.

Lintner, J. (1965) "The Valuation of Risk Assets and the Selection of Risky Investment in Stock Portfolios and Capital Budgets," Review of Economics and Statistics, 47, 13-37.

Lo, A. W. and A. C. MacKinlay (1990) "Data-Snooping Biases in Tests of Financial Asset Pricing Models," Review of Financial Studies, 3, 431-467.

Loughran, T. and J. R. Ritter (1995) “The New Issues Puzzle,” Journal of Finance, 50, 23-51.

Loughran, T. and A. M. Vijh (1997) “Do Long-Term Shareholders Benefit From Corporate Acquisitions?” Journal of Finance, 52, 1765-1790.

Lowry, M. and G. W. Schwert (2002) “IPO Market Cycles: Bubbles or Sequential Learning?” Journal of Finance, 57, 1171-1200. 
MacKinlay, A. C. (1995) "Multifactor Models Do Not Explain Deviations from the CAPM," Journal of Financial Economics, 38, 3-28.

Malkiel, B. G. (1995) “Returns from Investing in Equity Mutual Funds, 1971 to 1991,” Journal of Finance, 50, 549572 .

Mandelker, G. (1974) "Risk and Return: The Case of Merging Firms," Journal of Financial Economics, 1, 303-335.

Marsh, T. A. and R. C. Merton (1986) "Dividend Variability and Variance Bounds Tests for the Rationality of Stock Market Prices," American Economic Review, 76, 483-498.

Mitchell, M. L. and E. Stafford (2000) "Managerial Decisions and Long-Term Stock Price Performance," Journal of Business, 73, 287-320.

Mørck, R., A. Shleifer, and R. W. Vishny (1988) "Management Ownership and Market Valuation: An Empirical Analysis," Journal of Financial Economics, 20, 293-315.

Nelson, C. R. and G. W. Schwert (1977) "On Testing the Hypothesis That the Real Rate of Interest Is Constant," American Economic Review, 67, 478-486.

Odean, T. (1999) “Do Investors Trade Too Much?” American Economic Review, 89,1279-1298.

Pontiff, J. (1995) “Closed-End Fund Premia and Returns: Implications for Financial Market Equilibrium,” Journal of Financial Economics, 37, 341-370.

Pontiff, J. (1996) “Costly Arbitrage: Evidence from Closed-End Funds," Quarterly Journal of Economics, 111, $1135-1151$.

Reinganum, M. R. (1981) "Misspecification of Capital Asset Pricing: Empirical Anomalies Based on Earnings' Yields and Market Values," Journal of Financial Economics, 9, 19-46.

Reinganum, M. R. (1983) "The Anomalous Stock Market Behavior of Small Firms in January: Empirical Tests for Tax-Loss Selling Effects,” Journal of Financial Economics, 12, 89-104.

Ritter, J. R. (1991) “The Long-Run Performance of Initial Public Offerings,” Journal of Finance, 46, 3-27.

Roll, R. (1983) "Vas Ist Das? The Turn-of-the-Year Effect and the Return Premia of Small Firms," Journal of Portfolio Management, 9, 18-28.

Schultz, P. (2001) "Pseudo Market Timing and the Long-Run Underperformance of IPOs," manuscript, University of Notre Dame.

Schwert, G. W. (1983) "Size and Stock Returns, and Other Empirical Regularities," Journal of Financial Economics, 12, 3-12.

Schwert, G. W. (1989) “Why Does Stock Market Volatility Change Over Time?” Journal of Finance, 44, 11151153.

Schwert, G. W. (1990) "Indexes of United States Stock Prices from 1802 to 1987," Journal of Business, 63, 399426.

Schwert, G. W. (1991) "Review of Market Volatility by R. Shiller: Much Ado About . . Very Little," Journal of Portfolio Management, 17, 74-78.

Schwert, G. W. (1996) “Markup Pricing in Mergers \& Acquisitions,” Journal of Financial Economics, 41, 153-192. 
Sharpe, W. F. (1964) “Capital Asset Prices: A Theory of Market Equilibrium Under Conditions of Risk," Journal of Finance, 19, 425-442.

Shiller, R. J. (1981a) "Do Stock Prices Move Too Much to Be Justified by Subsequent Changes in Dividends?" American Economic Review, 75, 421-436.

Shiller, R. J. (1981b) "The Use of Volatility Measures in Assessing Market Efficiency," Journal of Finance, 36, 291-304.

Shiller, R. J. (1989) Market Volatility. Cambridge MA: MIT Press.

Shleifer, A. and R. W. Vishny (1997) “The Limits of Arbitrage,” Journal of Finance, 52, 35-55.

Smith, C. W. and R. L. Watts (1992) "The Investment Opportunity Set and Corporate Financing, Dividend, and Compensation Policies," Journal of Financial Economics, 32, 263-292.

Thompson, R. (1978) “The Information Content of Discounts and Premiums on Closed-end Fund Shares," Journal of Financial Economics, 6, 151-186. 